\title{
Recent Advances in Strategies for Addressing Hypoxia in Tumor Photodynamic Therapy
}

\author{
Liang Hong ${ }^{1}{ }^{\circledR}$, Jiangmin $\mathrm{Li}^{1}{ }^{1}$, Yali Luo ${ }^{1}$, Tao Guo ${ }^{1}$, Chenshuang Zhang ${ }^{2}$, Sha Ou ${ }^{1}$, Yaohang Long ${ }^{1}$ \\ and Zuquan $\mathrm{Hu}^{1, *}$
}

check for updates

Citation: Hong, L.; Li, J.; Luo, Y.; Guo, T.; Zhang, C.; Ou, S.; Long, Y.; $\mathrm{Hu}, \mathrm{Z}$. Recent Advances in Strategies for Addressing Hypoxia in Tumor Photodynamic Therapy. Biomolecules 2022, 12, 81. https://doi.org/ 10.3390/biom12010081

Academic Editor: Maoquan Chu

Received: 24 November 2021

Accepted: 29 December 2021

Published: 5 January 2022

Publisher's Note: MDPI stays neutral with regard to jurisdictional claims in published maps and institutional affiliations.

Copyright: (C) 2022 by the authors. Licensee MDPI, Basel, Switzerland. This article is an open access article distributed under the terms and conditions of the Creative Commons Attribution (CC BY) license (https:// creativecommons.org/licenses/by/ $4.0 /)$.
1 Key Laboratory of Environmental Pollution Monitoring and Disease Control of Ministry of Education, Immune Cells and Antibody Engineering Research Center of Guizhou Province, School of Biology and Engineering, Guizhou Medical University, Guiyang 550025, China; hongliang@gmc.edu.cn (L.H.); lijiangmin@stu.gmc.edu.cn (J.L.); luoyali@stu.gmc.edu.cn (Y.L.); guotao@stu.gmc.edu.cn (T.G.); ousha@gmc.edu.cn (S.O.); longyaohang@gmc.edu.cn (Y.L.)

2 Key Laboratory of Optoelectronic Devices and Systems of Ministry of Education and Guangdong Province, College of Optoelectronic Engineering, Shenzhen University, Shenzhen 518060, China;

1950453008@email.szu.edu.cn

* Correspondence: huzuquan@gmc.edu.cn

\begin{abstract}
Photodynamic therapy (PDT) is a treatment modality that uses light to target tumors and minimize damage to normal tissues. It offers advantages including high spatiotemporal selectivity, low side effects, and maximal preservation of tissue functions. However, the PDT efficiency is severely impeded by the hypoxic feature of tumors. Moreover, hypoxia may promote tumor metastasis and tumor resistance to multiple therapies. Therefore, addressing tumor hypoxia to improve PDT efficacy has been the focus of antitumor treatment, and research on this theme is continuously emerging. In this review, we summarize state-of-the-art advances in strategies for overcoming hypoxia in tumor PDTs, categorizing them into oxygen-independent phototherapy, oxygen-economizing PDT, and oxygen-supplementing PDT. Moreover, we highlight strategies possessing intriguing advantages such as exceedingly high PDT efficiency and high novelty, analyze the strengths and shortcomings of different methods, and envision the opportunities and challenges for future research.
\end{abstract}

Keywords: nanomaterials; photodynamic therapy; hypoxia; oxygen; tumor

\section{Introduction}

Cancer is one of the leading causes of disease-associated death in the world. Currently, traditional cancer treatment approaches face bottlenecks such as inadequate efficiency for destroying tumor and severe damage to normal tissues due to low selectivity. For example, surgery may cause severe influence on organ functions. Chemotherapy and radiotherapy are always accompanied by serious drug resistance and severe side effects, which lead to a serious influence on the life quality of patients [1]. Compared with traditional treatments, photodynamic therapy (PDT) provides advantages including high targeting ability, noninvasiveness, negligible side effects, maximal preservation of tissue functions, desired convenience, and high patient compliance [2]. Tumor PDT is a treatment modality that relies on cytotoxic reactive oxygen species (ROS) generated with a photosensitizer under light irradiation to kill cancer cells. It can be categorized into type I and type II PDT. The common PDT is type II PDT, as most photosensitizers are type II photosensitizers. Type II PDT kills tumor cells through the conversion of molecular oxygen to cytotoxic singlet oxygen $\left({ }^{1} \mathrm{O}_{2}\right.$, a type of ROS) with a photosensitizer, when it is delivered to the tumor and irradiated by light. In spite of enormous advantages, the application of PDT still faces great challenges, including the lack of effective photosensitizers, limited biological tissue penetration depth of light, and a harsh tumor microenvironment (TME) featured by severe hypoxia and other related characteristics [3]. 
Hypoxia is a salient and important feature of solid tumors. The typical oxygen pressure level in the tumor hypoxic area is below $2.5 \mathrm{~mm} \mathrm{Hg}$, whereas in normal tissues, the oxygen pressure suits metabolic requirements, and is usually above $40 \mathrm{~mm} \mathrm{Hg}[4,5]$. The hypoxia is derived from the rapid tumor cell proliferation and abnormal tumor vascular system. It is widely recognized that hypoxia promotes tumor angiogenesis, metastasis, and resistance to many therapies including chemotherapy, radiotherapy, and PDT [6]. In particular, hypoxia impedes type II PDT efficiency severely, since oxygen is a critical component for type II PDT. What is worse, hypoxia is aggravated during the type II PDT process due to the oxygen consumption and vascular closure. In addition, hypoxia inhibits the immune response triggered by type II PDT [7]. In a word, hypoxia is a major stumbling block of type II PDT.

Currently, the development of strategies for addressing tumor hypoxia in type II PDT is a focus for cancer research, and novel approaches and attractive nanomaterials are continuously emerging. This review summarizes the cutting-edge progress on approaches to address tumor hypoxia and improve PDT, analyzes the strengths and shortcomings of these approaches, and puts forward potential challenges and future opportunities for further research. To define clearly the scope of this article, this review focuses on the methods that directly address tumor hypoxia and advance light-activated PDT. Therefore, some excellent methods that affect hypoxia indirectly, such as suppression of hypoxiarelated proteins including hypoxia inducible factor- $1 \alpha$ (HIF-1 $\alpha)$, or approaches that do not involve light application, such as the employment of hypoxia-activable drugs (e.g., tirapazamine [8] and banoxantrone (AQ4N)) [9], are not included in this article. The discussion on these outstanding tactics can be found in other review articles $[5,10,11]$.

\section{Strategies for Modulating Tumor Hypoxia in PDT}

Early strategies for overcoming tumor hypoxia in type II PDT include hyperbaric oxygen breathing and inhaling pure oxygen or carbogen ( $95 \%$ oxygen $+5 \%$ carbon dioxide) at atmospheric pressure [12]. These methods, nontheless, have gained limited achievements due to their insufficient therapeutic efficacy and side effects such as hyperoxic seizures and barotrauma [13].

Recent strategies focus on the development of advanced nanomedicines that could address hypoxia and simultaneously improve PDT efficacy. The innovation of nanomaterials has become the core impetus for the development of PDT for hypoxic tumors. These nanomaterial-based strategies can be categorized into three domains, including oxygen-independent phototherapy, oxygen-economizing PDT, and oxygen-supplementing PDT.

\subsection{Oxygen-Independent Phototherapy}

The major merit of PDT, i.e., high tumor-targeting ability which facilitates prevention of damage to normal tissues, originates from the controllable and tunable nature of light and the cytotoxic effect of ROS. However, typical oxygen-dependent ROS production severely limits type II PDT efficiency. Therefore, therapeutic modalities which can generate cytotoxic substance other than ROS, or cytotoxic physical effect under light irradiation, might overcome oxygen dependence while keeping the high tumor specificity. Meanwhile, light-enhanced Fenton/Fenton-like reaction and type I PDT could circumvent the tumor hypoxia issue.

\subsubsection{Photogenerated Hole Therapy}

Different from the traditional ${ }^{1} \mathrm{O}_{2}$-producing PDT, a novel highly efficient phototherapy was developed by Zhang et al. based on the generation of photogenerated holes (Figure 1) [14]. Photogenerated holes are high-energy oxidation states formed on the semiconductor photocatalyst surface after excitation by light [15]. The photogenerated holes could exert a strong oxidation effect on cancer cells, causing cancer cell death. As the formation of photogenerated holes does not rely on oxygen, the treatment efficiency could be improved. Of note, an unprecedentedly high therapeutic efficiency was achieved by this 
treatment modality. Supramolecular photocatalysts of self-assembled tetra-carboxyphenyl porphyrin (SA-TCPP) were prepared and administrated into subcutaneous tumor-bearing mice. After irradiation with a $600 \mathrm{~nm}$ light of $0.1 \mathrm{~W} \mathrm{~cm}^{-2}$ for 10 minutes, the tumors $\left(100 \mathrm{~mm}^{3}\right)$ were completely eliminated. Within $10 \mathrm{~min}$, the solid tumor site was atrophied and flattened. On the second day, the irradiated part was scarred. One week later, the scars fell off, and newly reconvened tissues were revealed. After 50 days, all the treated mice were healthy, whereas none of the untreated control group mice survived. In addition to the extraordinary therapeutic efficiency, this treatment modality showed satisfactory biosafety. This therapy opened up new possibilities for hypoxic tumor phototherapy. With further development, the photogenerated hole therapy may play a significant role in tumor treatment.
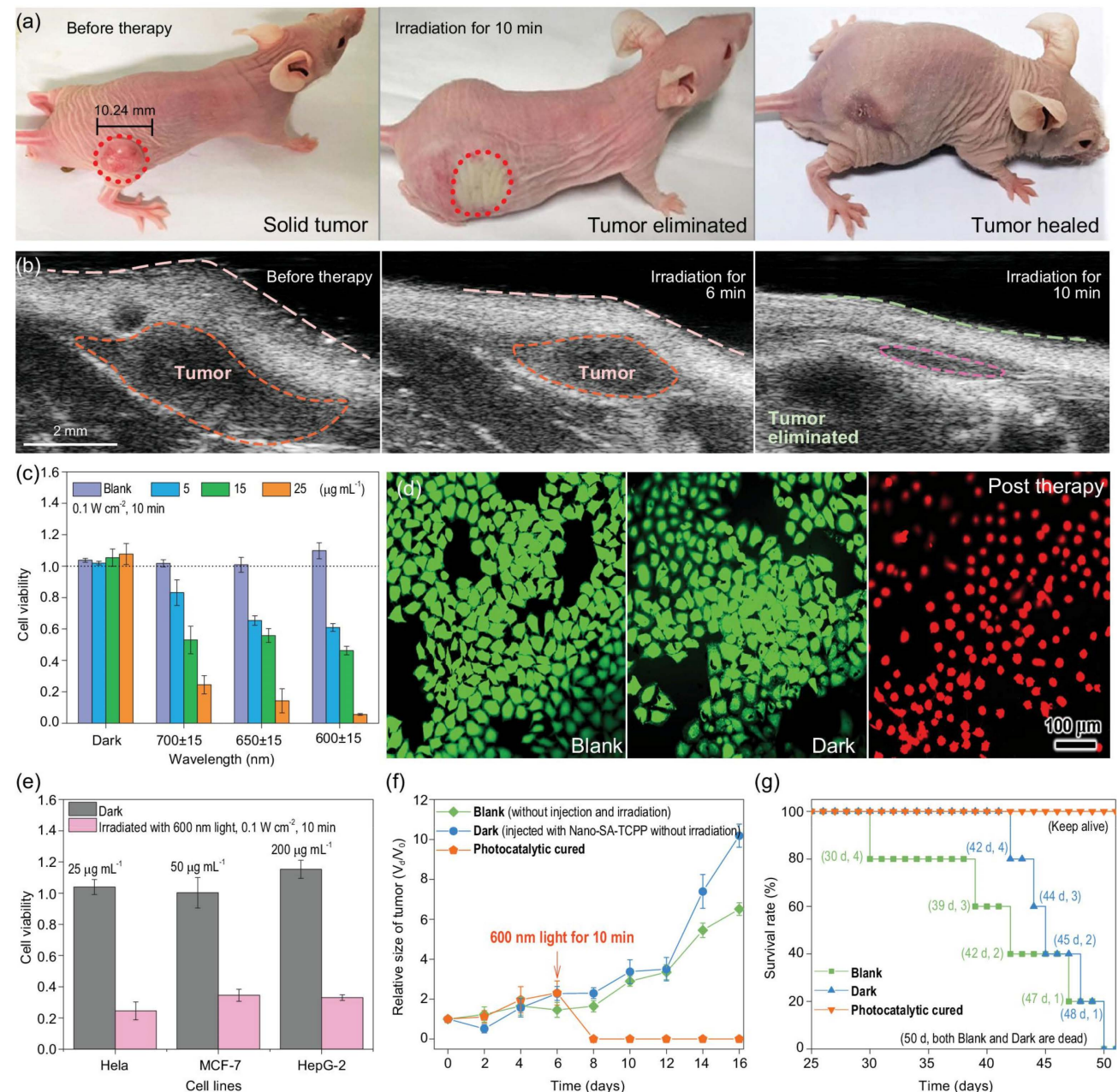

Figure 1. The photogenerated hole therapy with Nano-SA-TCPP. (a) The images of photogenerated hole therapy for tumor-bearing mice (irradiation condition: $600 \mathrm{~nm}, 0.1 \mathrm{~W} \mathrm{~cm}^{-2}$ ). (b) The ultrasound pictures of tumors before and after photogenerated hole therapy (irradiation condition: $600 \mathrm{~nm}$, $0.1 \mathrm{~W} \mathrm{~cm}^{-2}$ ). (c) The viability of Hela cells with various concentrations of Nano-SA-TCPP under light irradiation. (d) Fluorescence images of living (green) and dead (red) Hela cells (irradiation condition: $600 \mathrm{~nm}, 0.1 \mathrm{~W} \mathrm{~cm}^{-2}$ ). (e) Photogenerated hole therapy on diverse cancer cell lines (irradiation condition: $600 \mathrm{~nm}, 0.1 \mathrm{~W} \mathrm{~cm}^{-2}$ ). (f) Relative tumor volumes of mice. (g) Survival rates of mice. Nano-SA-TCPP, nano-self-assembled tetra-carboxyphenyl porphyrin. Reprinted with permission from Ref. [14]. Copyright 2020 Oxford University Press.

\subsubsection{Photoacoustic Therapy}

The photoacoustic effect describes the formation of acoustic waves following absorption of light pulses. It has been utilized for causing mechanical destruction of cancer 
cells [16]. Because of its oxygen-independent nature, photoacoustic effect provides an effective approach for addressing hypoxia in PDT. A recent research demonstrated that under pulse laser irradiation, gadolinium(III)-phthalocyanine (GdPc) could simultaneously produce an intense acoustic effect and a large amount of ${ }^{1} \mathrm{O}_{2}$. Combinatorial inhibition of tumors was detected under either normal or hypoxic conditions [17].

\subsubsection{Photo-Acid Therapy}

In 2013, Yue et al. developed a novel photo-acid therapy to overcome hypoxia in tumor PDT treatment (Figure 2) [18]. Photoacid generators (PAGs) are molecules which could generate a $\mathrm{pH}$ drop when irradiated by light. Sulfonium salts were traditionally used as PAGs in lithography and cationic polymerization, and they could produce photoacid under excitation by ultraviolet or deep-ultraviolet light. However, the short wavelength limited the biological tissue penetration depth, impeding deep-seated tumor treatment. To shift the light wavelength to the visible and near-infrared (NIR) light range, Yue et al. designed and synthesized more conjugated and two-photon absorbing sulfonium salts. These sulfonium salts induced considerable cancer cell death through generating a $\mathrm{pH}$ drop in the cytosol under light irradiation, and showed low cytotoxicity in the dark.

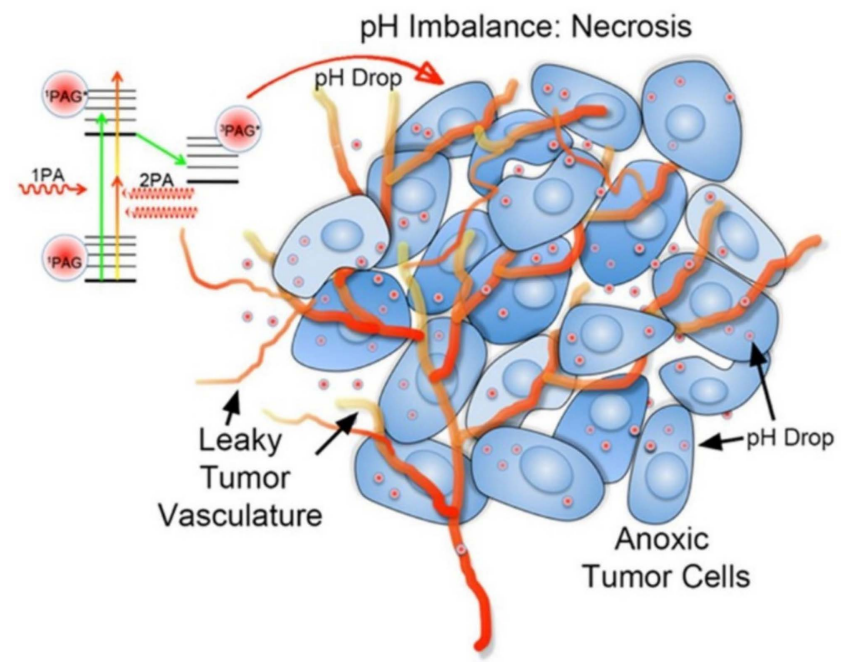

Figure 2. Schematic illustration of photo-acid therapy with photoacid generators (PAGs) under two-photon excitation. Adapted with permission from Ref. [18]. Copyright 2013 American Chemical Society.

Later in 2016, polyethylene glycol (PEG)-functionalized and hydrophilic silica nanoparticleenriched PAGs were developed for increasing aqueous solubility and effectively inducing cancer cell death [19]. In 2019, a novel iridium(III)-based PAG was synthesized for mitochondria-targeted dual-mode (oxygen-independent and oxygen dependent) tumor phototherapy [20]. This iridium(III)-based PAG was able to produce photoacid under light irradiation in hypoxic environment, and its photolysis products could further sensitize ${ }^{1} \mathrm{O}_{2}$ generation. Moreover, it is noteworthy that in 2019, Tian et al. constructed a new PAG which could generate large $\mathrm{pH}$ jumps at low concentrations [21]. This feature is important for tumor photo-acid therapy, and is worthy of further exploration. With further development, photo-acid therapy may play an important role in hypoxic tumor treatment.

\subsubsection{Photo-Induced Alkyl Radical Generation Therapy}

Recently, a growing number of studies have focused on the oxygen-independent photoinduced alkyl radical generation for tumor treatment [22]. Alkyl radicals and ROS are both free radicals that could damage cancer cells. However, the production of alkyl radicals from azo compounds does not rely on oxygen, and could be induced by heat stimulation. In this context, in 2019, Xia et al. conjugated a photothermal porphyrin with an alkyl radical 
initiator to obtain a new kind of nanoparticles denoted as TPP-NN NPs (Figure 3) [23]. Under NIR light irradiation, TPP-NN NPs could split and release alkyl radicals, causing cancer cell death in both normoxic and hypoxic conditions. In vitro and in vivo studies showed that the photothermal-controlled production of alkyl radicals could exert excellent anticancer effects with negligible systemic toxicity. Similarly, another photothermal agent, semiconducting polymer nanoparticles, were combined with an alkyl radical initiator and exhibited satisfactory antitumor effects under NIR irradiation [24].
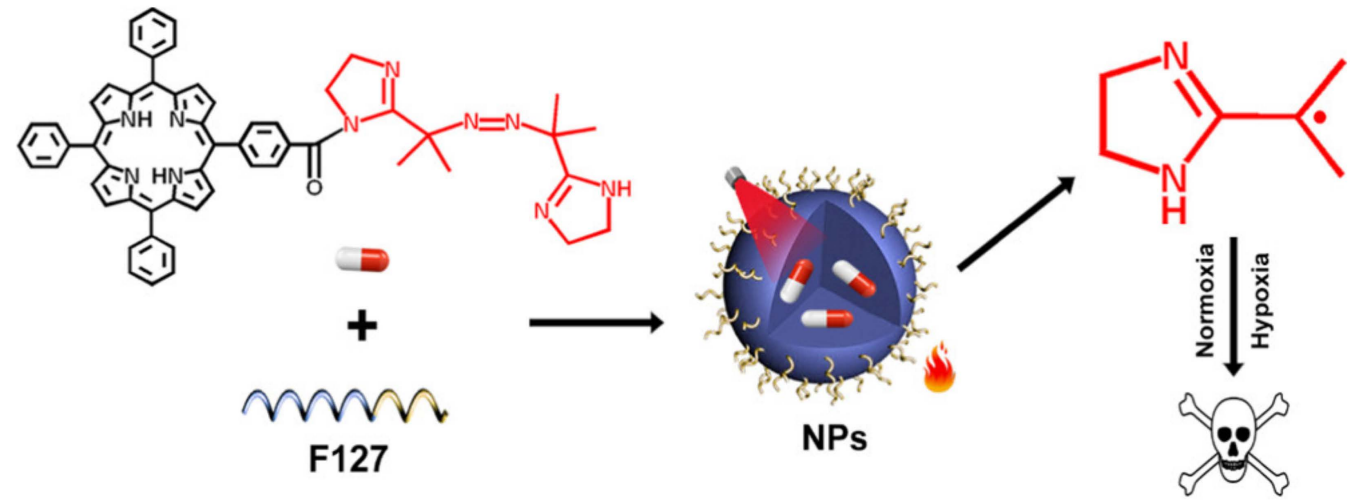

Cell death

Figure 3. Schematic illustration of the structure of TPP-NN NPs and the mechanism of photo-induced alkyl radical generation therapy. Reprinted with permission from Ref. [23]. Copyright 2019 American Chemical Society.

The overproduced glutathione in TME could scavenge free radicals; therefore, it severely limits the efficiency of photo-induced alkyl radical therapy. In this context, a synergistic antitumor platform named $\mathrm{MoS}_{2} @ \mathrm{AIBI}-\mathrm{PCM}$ nanoflowers was developed [25]. The polyethylene-glycol-functionalized molybdenum disulfide (PEG-MoS 2 ) facilitated GSH depletion and improved the therapeutic efficacy.

\subsubsection{Light-Enhanced Fenton/Fenton-like Reaction}

Arising from the chain reaction between two valence iron $\left(\mathrm{Fe}^{2+}\right)$ and hydrogen peroxide $\left(\mathrm{H}_{2} \mathrm{O}_{2}\right)$, Fenton reaction could generate hydroxyl radicals $(\cdot \mathrm{OH})$ with significantly higher oxidation performance than ${ }^{1} \mathrm{O}_{2}\left(\mathrm{E}\left(\cdot \mathrm{OH} / \mathrm{H}_{2} \mathrm{O}\right)=2.80 \mathrm{~V}, \mathrm{E}\left({ }^{1} \mathrm{O}_{2} / \mathrm{H}_{2} \mathrm{O}\right)=2.17 \mathrm{~V}\right)$ [26]. The typical Fenton reaction scheme is as follows: $\mathrm{Fe}^{2+}+\mathrm{H}_{2} \mathrm{O}_{2} \rightarrow \mathrm{Fe}^{3+}+\cdot \mathrm{OH}+\mathrm{OH}^{-}$. It has been recognized that ultraviolet/visible light irradiation could prominently improve the efficiency of Fenton reactions $[27,28]$. Therefore, light-enhanced Fenton reactions serve as an intriguing modality for cancer treatment, with the tumor-targeting ability endowed by light and oxygen-independent property arising from the Fenton reactions. To facilitate deep-seated tumor treatment, the light wavelength can be transformed to NIR using upconversion nanoparticles (UCNP) [27]. However, the mild acidity ( $\mathrm{pH}$ 6.5-6.9) of TME seriously lowers the efficiency of light-enhanced Fenton reactions, since the suitable $\mathrm{pH}$ range for Fenton reaction is 3-4 [29]. Aside from $\mathrm{pH}$ value, the low $\mathrm{H}_{2} \mathrm{O}_{2}$ amount in the tumor microenvironment also hampers the efficiency of light-enhanced Fenton reactions. Currently, to boost the efficiency of light-enhanced Fenton reactions, the following approaches have been applied and demonstrated to be effective, including (1) light-induced temperature elevation [30-33], (2) decreasing tumor environment $\mathrm{pH}$ [34], (3) increasing tumor $\mathrm{H}_{2} \mathrm{O}_{2}$ level [35], and (4) development of Fenton-like reactions that have better efficiency at neutral or mildly acidic $\mathrm{pH}[36,37]$.

For instance, Dong et al. prepared a nanoplatform containing $\gamma-\mathrm{Fe}_{2} \mathrm{O}_{3}$ and natural glucose oxidase (GOx) (Figure 4) [32]. The $\gamma-\mathrm{Fe}_{2} \mathrm{O}_{3}$ served as both photothermal therapy (PTT) agent and Fenton catalyst. Upon $808 \mathrm{~nm}$ light irradiation, the PTT-induced temperature elevation remarkably improved the Fenton reaction efficiency. Moreover, the GOx 
could significantly consume glucose in the tumor cells, resulting in pH decrease and $\mathrm{H}_{2} \mathrm{O}_{2}$ generation, facilitating the Fenton reaction. This research highlighted the great potential of the phototherapy combining PTT, Fenton reaction, and glucose starvation therapy.

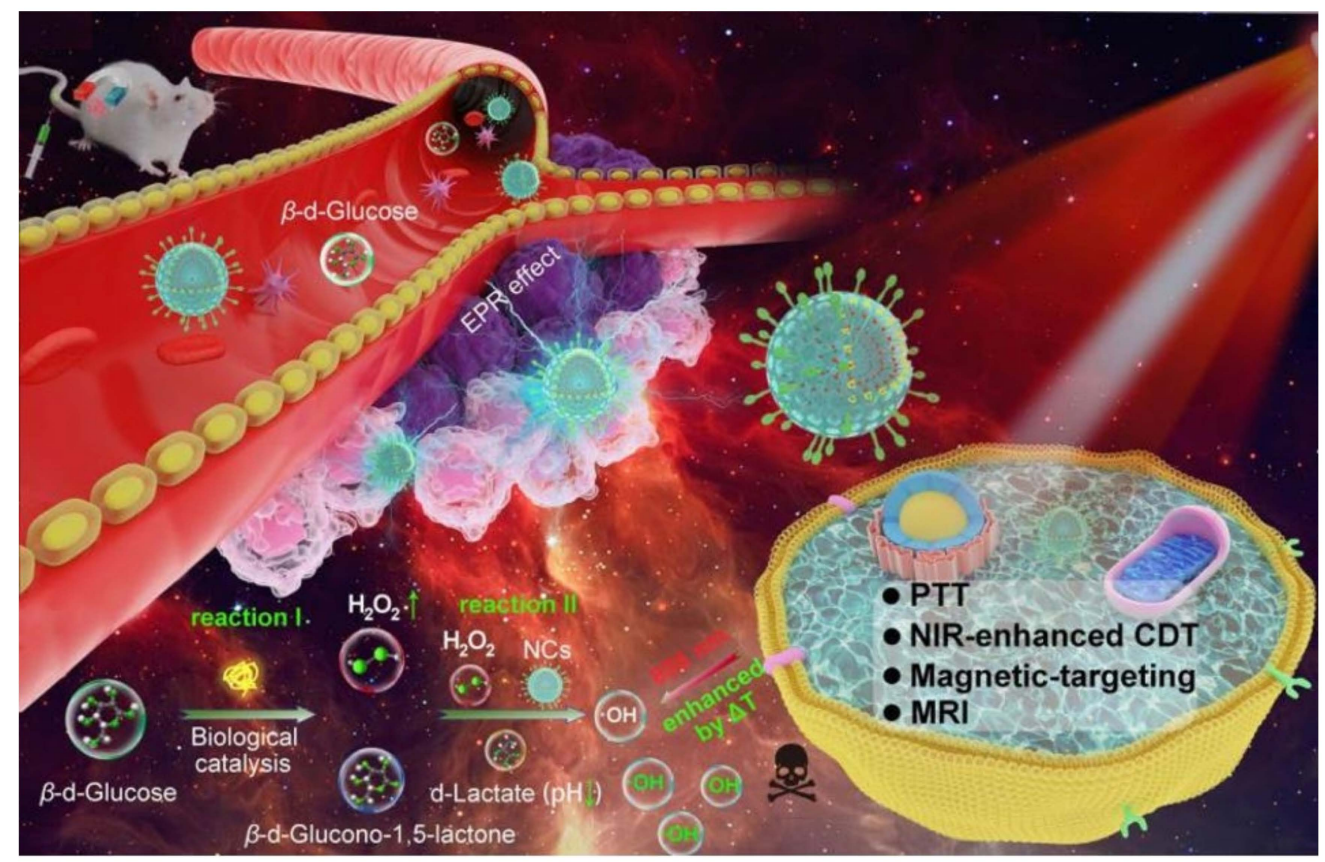

Figure 4. Schematic illustration of $\mathrm{H}_{2} \mathrm{O}_{2}, \mathrm{pH}$, and photothermal-enhanced Fenton reaction based on $\gamma-\mathrm{Fe}_{2} \mathrm{O}_{3}$-GOx-DMSN for hypoxic tumor therapy. Adapted with permission from Ref. [32]. Copyright 2020 American Chemical Society.

Light-enhanced Fenton-like reactions that have high efficiency at neutral or slightly acidic conditions were also investigated for hypoxic tumor therapy. For example, Wang et al. prepared $\mathrm{Cu}_{2} \mathrm{Se}$ hollow nanocubes which have excellent Fenton-like properties at neutral $\mathrm{pH}$, and as well high NIR II (1000-1350 nm) photothermal conversion efficiency [38]. Under NIR II light irradiation, the photothermal effect may remarkably improve the efficiency of Fenton-like reactions, causing efficient tumor destruction. The deep tissue penetration depth of NIR II light is beneficial for the treatment of deep-seated tumors.

\subsubsection{Type I PDT}

When excited by light, a photosensitizer converts from the ground state to an unabiding singlet state $\left({ }^{1} \mathrm{PS}^{*}\right)$. This transient singlet state has two alternative routes [5]. Firstly, the singlet state is transformed back to the ground state accompanying fluorescence (which facilitates tumor imaging) emission or heat generation; secondly, the singlet state is converted into the excited triplet state $\left({ }^{3} \mathrm{PS}^{*}\right)$ with a long lifetime, which could undergo type I or type II reaction pathways [39]. In most cases, photosensitizers generate ROS via type II process, where oxygen is indispensable. In this process, the photosensitizers in the excited triplet state transfer energy to molecular oxygen $\left({ }^{3} \mathrm{O}_{2}\right)$, resulting in generation of ${ }^{1} \mathrm{O}_{2}$, a type of ROS. Nevertheless, in the type I process, ROS including superoxide anion $\left(\mathrm{O}_{2}{ }^{\bullet-}\right)$ and $\cdot \mathrm{OH}$, are produced by transferring electron/hydrogen when photosensitizers interact with substrates (biomolecules). Therefore, type I PDT is oxygen-independent. In tumor PDT, the cytotoxic ROS leads to cancer cell death. The mechanism of type I and type II PDT is presented in Figure 5. 


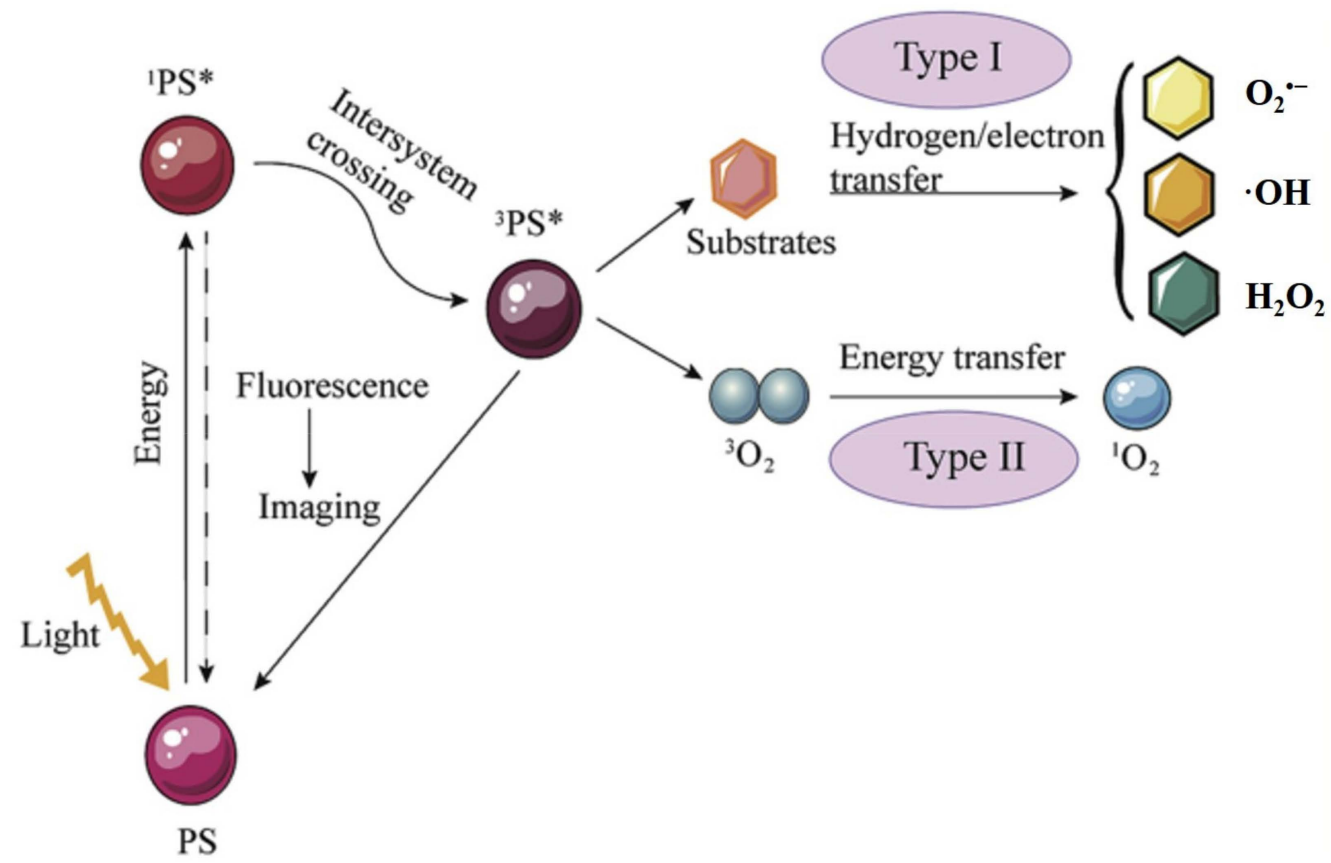

Figure 5. Schematic illustration of the mechanism of type I and type II photodynamic therapy. PS, photosensitizer. Adapted with permission from Ref. [5]. Copyright 2020 Elsevier.

Because of the oxygen-independent property of type I PDT, a variety of materials were designed and prepared to regulate the PDT mechanism and enhance type I PDT [40-47]. It is recognized that for the majority of photosensitizers, type I and II pathways typically exist simultaneously but competitively [48-51]. Till now, full understanding of the mechanism of transformation from type II to type I mechanism is still a great challenge. However, recent studies suggest that the electronic environment around the photosensitizer, or the electron donor groups, may play an important role in the evolution from type II to type I mechanism. It has been demonstrated that the Type I photochemical mechanism of various photosensitizers, can be enhanced via (1) physical encapsulation and (2) chemical modification [52-54]. For instance, Ding et al. studied the effect of the micelle carrier microenvironment on the photophysical features of a photosensitizer 5,10,15,20-tetrakis(mesohydroxyphenyl)porphyrin (mTHPP) [55]. Electron-rich poly(2-(diisopropylamino)ethyl methacrylate) (PDPA) micelle encapsulation increased type I reactions generating superoxide radical anions, whereas the electron-deficient poly(D,L-lactide) micelle encapsulation produced ${ }^{1} \mathrm{O}_{2}$ as predominant species by type II mechanisms. Consequently, the electronrich PDPA micelle encapsulation increased the ability to kill cancer cells under aerobic conditions. Similarly, a recent research encapsulated a synthesized photosensitizer boron difluoride dipyrromethene (BODIPY)-vadimezan conjugate (BDPVDA), into an electron-rich amphiphilic polymer methoxy-poly(ethylene glycol)-b-poly(2-(diisopropylamino) ethyl methacrylate) (mPEG- PPDA), to obtain PBV NPs [56]. The PBV NPs achieved highly efficient type I PDT even under extremely hypoxic conditions $\left(2 \% \mathrm{O}_{2}\right)$ because of its extraordinary core-shell intermolecular electron transfer. Moreover, Li et al. prepared a novel nanodot by self-assembly of 2,4,6-tris-( $N, N$-dimethylaminomethyl)phenoxy substituted zinc(II) phthalocyanine, PcA [57] for highly efficient type I photoreactions. The PcA nanodots having amino groups showed high superoxide anion generation efficiency, whereas its counterpart without amino groups generated no superoxide anion. This suggested the significant role of electron donor groups in the enhancement of type I mechanism. Nevertheless, the mechanism of transformation from type II to type I pathway may be complicated, and needs to be further studied.

In addition to the abovementioned modalities, oxygen-independent photo-induced carbon monoxide generation [58] were also developed to address hypoxia in PDT. 


\subsection{Oxygen-Economizing PDT}

\subsubsection{Mitochondria Inhibition}

Very recently, increasing attention has been drawn to the inhibition of the oxidative phosphorylation (OXPHOS) pathway in mitochondria of cancer cells in order to economize oxygen for PDT reactions. Although tumors acquire energy predominantly via the "Warburg effect" [59], seriously accelerated OXPHOS was still observed in considerable malignant cell lines during tumorigenesis, development, and metastasis [60,61]. Consequently, diverse mitochondria respiratory chain inhibitors, including $\alpha$-tocopherol succinate [62], papaverine [63], atovaquone [64-68], tamoxifen [69,70], metformin [71-77], and nitric oxide (NO) [78-81], have been used for reducing oxygen consumption and increasing PDT efficiency. For example, a nanoplatform was prepared through incorporating L-Arginine and a photosensitizer chlorin e6 with poly-lactic-co-glycolic acid (PLGA) (Figure 6) [79]. The L-Arginine could be transformed to $\mathrm{NO}$ after reaction with the over-expressed $\mathrm{H}_{2} \mathrm{O}_{2}$ in the tumor. The NO inhibited the mitochondrial Complex IV (Cytochrome C oxidase) and reduced oxygen consumption to increase PDT efficiency. The inhibition of the mitochondrial Complex IV also retarded adenosine triphosphate (ATP) production, which could sensitize the tumor cells for PDT.

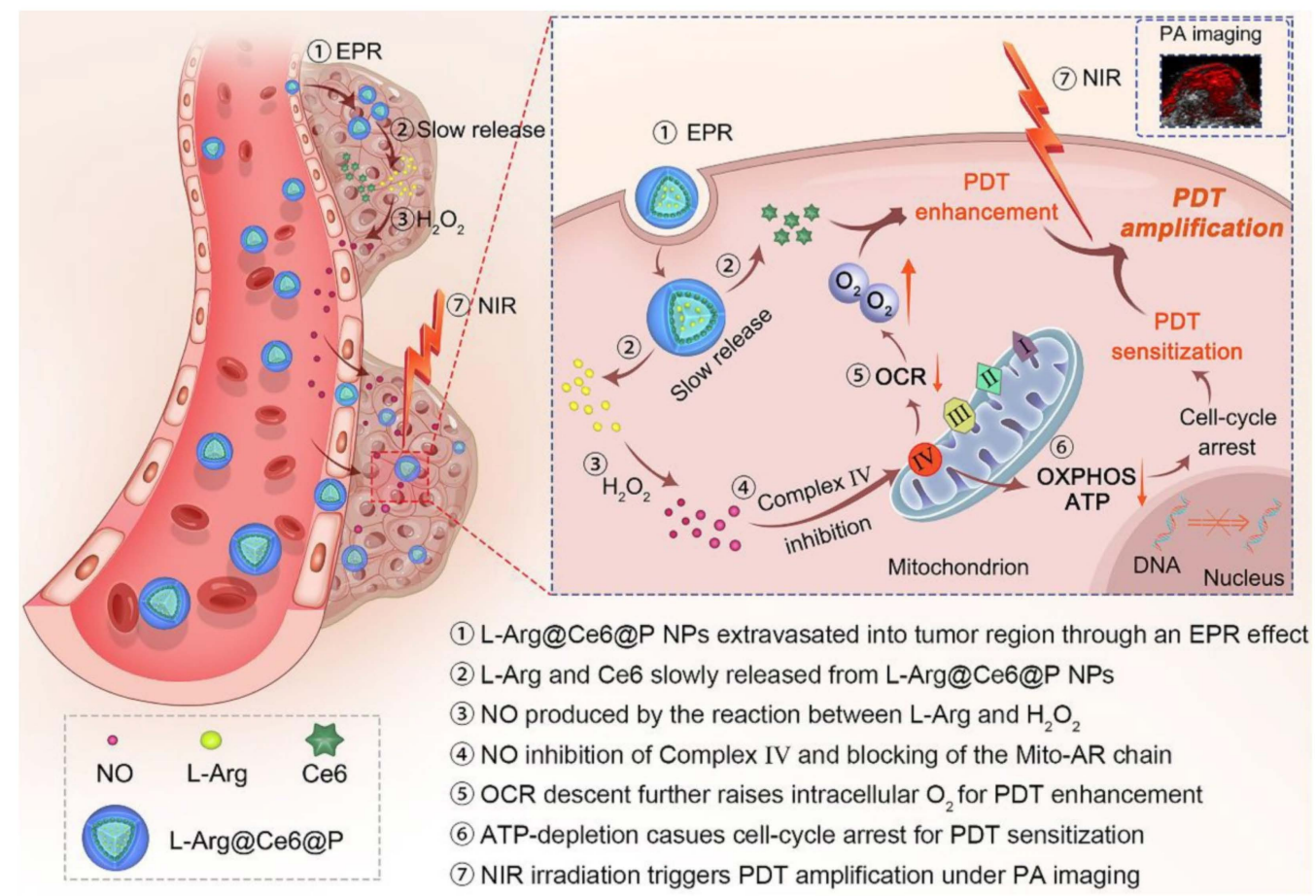

Figure 6. NO-based theranostic nanocomposite which enhances PDT efficiency via economizing oxygen and impeding ATP synthesis. EPR, enhanced permeability and retention. OXPHOS, oxidative phosphorylation. ATP, adenosine triphosphate. NIR, near-infrared. PA, photoacoustic. Reprinted with permission from Ref. [79]. Copyright 2021 Ivyspring International Publisher.

\subsubsection{Fractional PDT}

Tumor hypoxia is exacerbated during type II PDT process due to the consumption of oxygen by type II PDT reactions. Fractional PDT uses fractionated (i.e., intermittent) light irradiation instead of continuous light irradiation to activate the photosensitizer, allowing for oxygen replenishment during breaks between irradiation periods. Fractional PDT makes full use of the oxygen available. Many studies suggest that fractional PDT may improve treatment efficiency [82-85]. In addition to the modification of irradiation protocols, efforts have been made towards improvement of photosensitizers in fractional PDT. To further enhance fractional PDT, Turan et al. incorporated boron-dipyrromethene (BODIPY) with 2-pyrdidone to obtain a novel photosensitizer named PYR6 [83]. Upon light 
irradiation (light cycle), PYR6 generated ${ }^{1} \mathrm{O}_{2}$, some of which was absorbed by reaction with 2-pyridone to form the corresponding endoperoxide, that is, EPO7. When light irradiation was paused (dark cycle), EPO7 released ${ }^{1} \mathrm{O}_{2}$ because of a thermal cycloreversion of the endoperoxide and regenerated PYR6. As a result, the photodynamic process could continue in the dark as well as in the light cycles. In vitro experiments demonstrated that this new fractional PDT approach based on PYR6 obviously increased PDT efficiency. In addition, multiple photosensitizer injections might also improve hypoxic tumor PDT efficiency via palliating the problem of photochemical consumption of oxygen.

\subsection{Oxygen-Supplementing PDT}

Oxygen-supplementing PDT provides the advantage that it could attenuate hypoxiarelated issues such as drug-resistant gene expression. The methods for supplementing oxygen in tumor PDT can be categorized mainly into six routes. The merits and limitations of these routes are summarized in Table 1.

Table 1. A summary of the representative materials, strengths, and shortcomings of different approaches for oxygen-supplementing PDT. ROS, reactive oxygen species.

\begin{tabular}{|c|c|c|c|}
\hline Strategy & $\begin{array}{l}\text { Representative } \\
\text { Materials }\end{array}$ & Strengths & Shortcomings \\
\hline $\begin{array}{c}\text { Increasing oxygen } \\
\text { utilization efficiency } \\
\text { using } \\
\text { micro-/nanomotors }\end{array}$ & $\begin{array}{l}\text { Poly(ethylene glycol) } \\
\text { block polystyrene, } \\
\mathrm{Fe}_{3} \mathrm{O}_{4} \\
\text { nanoparticle-loaded } \\
\text { hemoglobin }\end{array}$ & $\begin{array}{c}\text { Deep tumor } \\
\text { penetration through } \\
\text { movement }\end{array}$ & $\begin{array}{l}\text { Maximum efficiency } \\
\text { limited by oxygen } \\
\text { concentration }\end{array}$ \\
\hline $\begin{array}{l}\text { Living organism } \\
\text { oxygen generators }\end{array}$ & $\begin{array}{c}\text { Chlorella, } \\
\text { Cyanobacteria, } \\
\text { Spirulina, and } \\
\text { thylakoid membrane } \\
\text { of green plants }\end{array}$ & $\begin{array}{c}\text { Synchronous } \\
\text { activation of oxygen } \\
\text { supply and ROS } \\
\text { generation, } \\
\text { abundance of water } \\
\text { in the human body } \\
\text { beneficial for oxygen } \\
\text { generation }\end{array}$ & $\begin{array}{l}\text { Harsh tumor } \\
\text { microenvironment } \\
\text { harming organism } \\
\text { activity; micrometer } \\
\text { size limiting deep } \\
\text { tumor penetration; } \\
\text { light wavelengths in } \\
\text { visible light range }\end{array}$ \\
\hline $\begin{array}{l}\text { Light-driven water } \\
\text { splitting }\end{array}$ & $\begin{array}{l}\text { Tungsten nitride, } \\
\text { carbon nanodot, } \\
\text { graphdiyne oxide, } \\
\text { iron disulfide, cobalt } \\
\text { phytate, } \mathrm{C}_{3} \mathrm{~N}_{4}\end{array}$ & $\begin{array}{c}\text { Synchronous } \\
\text { activation of oxygen } \\
\text { supply and ROS } \\
\text { generation, } \\
\text { abundance of water } \\
\text { in the human body } \\
\text { for oxygen } \\
\text { production }\end{array}$ & $\begin{array}{l}\text { Safety concern due to } \\
\text { presence of metal ions }\end{array}$ \\
\hline $\begin{array}{l}\text { Modification of tumor } \\
\text { blood circulation }\end{array}$ & $\begin{array}{l}\text { Heparin, warm water } \\
\text { bath }\end{array}$ & $\begin{array}{c}\text { Concurrent } \\
\text { improvement of light } \\
\text { delivery }\end{array}$ & $\begin{array}{l}\text { Weak effect on tumor } \\
\text { regions distant from } \\
\text { blood vessels }\end{array}$ \\
\hline $\begin{array}{c}\text { Tumor } \mathrm{H}_{2} \mathrm{O}_{2} \\
\text { decomposition }\end{array}$ & $\begin{array}{c}\text { Metal-based } \\
\text { materials, catalase }\end{array}$ & $\begin{array}{l}\text { Inherent tumor } \\
\text { specificity }\end{array}$ & $\begin{array}{l}\text { Efficiency limited by } \\
\mathrm{H}_{2} \mathrm{O}_{2} \text { concentration }\end{array}$ \\
\hline Oxygen delivery & $\begin{array}{l}\text { Hemoglobin, } \\
\text { perfluorocarbon, } \\
\text { metal-organic } \\
\text { frameworks }\end{array}$ & High efficiency & $\begin{array}{l}\text { Lack of inherent } \\
\text { tumor specificity }\end{array}$ \\
\hline
\end{tabular}

\subsubsection{Increasing Oxygen Utilization Efficiency Using Micro-/Nanomotors}

The employment of synthetic micro-/nanomotors is an emerging strategy for overcoming tumor hypoxia and improving PDT [86-89]. Micro-/nanomotors are micro-/nano particles which can convert different energy (chemical energy or other external energy resources including light, electronic, and magnetic fields) to propulsion for autonomous 
movement. Because of their movement property, these motors may increase the oxygen utilization efficiency and boost hypoxic tumor PDT via at least two pathways: (1) The motion characteristic of motors facilitates blood vessel and tissue penetration [90,91]. This is beneficial for the penetration of oxygen and photosensitizers to the central hypoxic aeras of tumors, leading to inhibition of tumor metastasis and more effective tumor destruction. (2) These motors may promote the diffusion of oxygen and photosensitizers inside tumor cells, resulting in expanded distribution of generated ROS in the tumor site. This may overcome the PDT deficiency caused by the limited diffusion range of ROS, and consequently lead to simultaneous destruction of multiple important organelles, resulting in accelerated cancer cell death.

For instance, recently Zhang et al. constructed a nanomotor composed of self-assembly stomatocyte-like structure of poly(ethylene glycol) block polystyrene (PEG- $b$-PS), iron oxide nanoparticles (IONPs) and the photosensitizer zinc phthalocyanine ( $\mathrm{ZnPc}$ ) (Figure 7) [86]. The as-prepared nanomotor was denoted as ISP-NMs. The stomatocyte-like structure conferred the system movement function. Because of magnetism of IONPs, the nanomotors could accumulate effectively in tumor sites under magnetic field guidance. After reaching the tumor, IONPs could decompose tumor endogenous $\mathrm{H}_{2} \mathrm{O}_{2}$ to form oxygen as propelling force for ISP-NMs movement. Fluorescence images showed that the oxygen-propelled movement prominently enlarged the intracellular distribution of photosensitizers. Accordingly, the movement of ISP-NMs enhanced PDT efficiency. In vitro studies on Hela cells showed that ISP-NMs killed more cancer cells than ZnPc\&IONPs, and in vivo studies on tumor-bearing mice demonstrated that ISP-NMs suppressed tumor growth more remarkably than $\mathrm{ZnPc} \& I O N P s$.

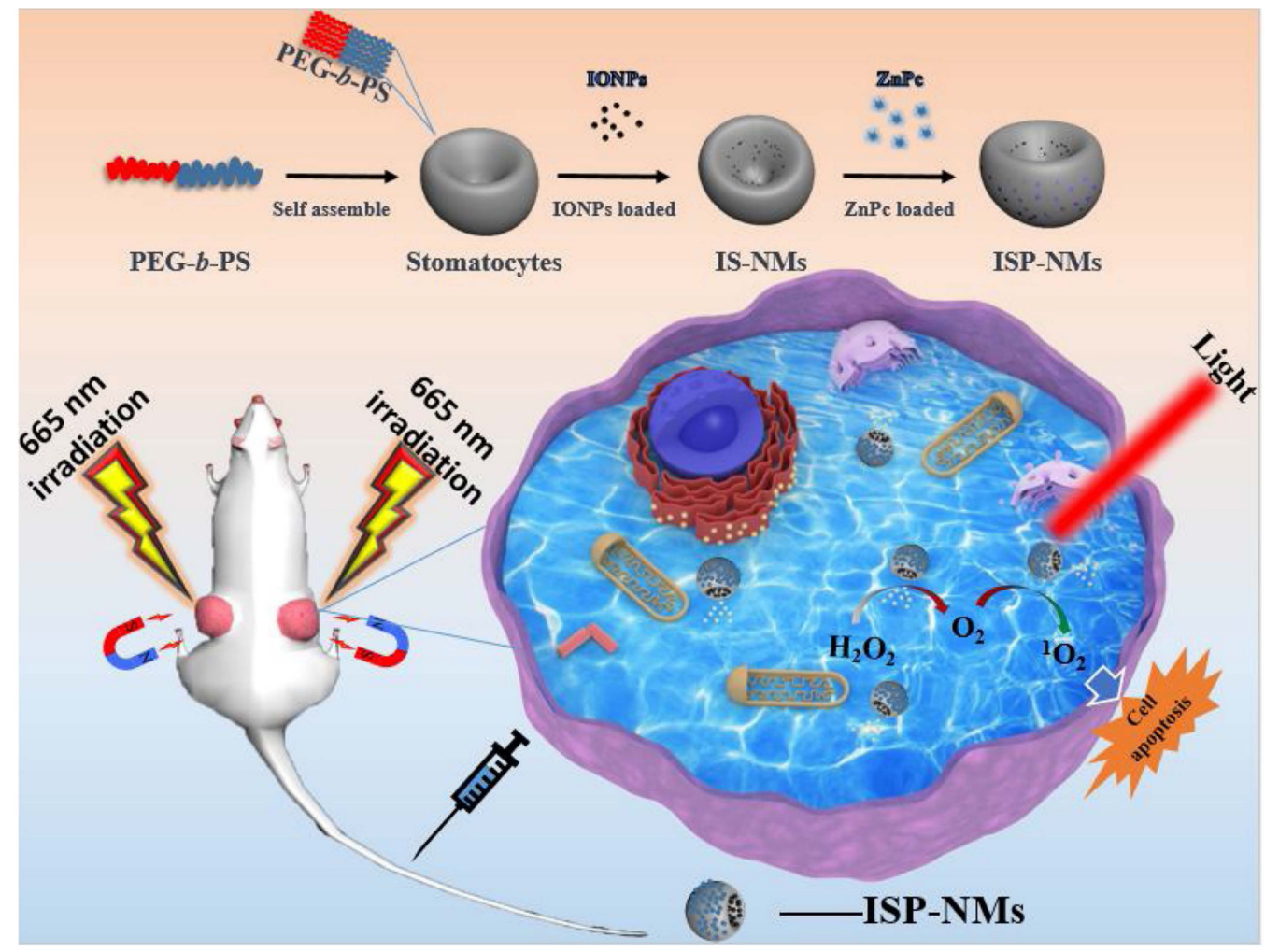

Figure 7. Preparation of ISP-NMs and mechanism of nanomotor-mediated photodynamic therapy. PEG- $b$-PS, poly(ethylene glycol) block polystyrene. IONP, iron oxide nanoparticle. ZnPc, zinc phthalocyanine. Reprinted with permission from Ref. [82]. Copyright 2020 Elsevier.

For another instance, Gao et al. prepared a red-blood-cell-mimicking (RBCM) micromotor that could actively transport oxygen and photosensitizer for improved PDT [87]. The RBCM micromotors contain $\mathrm{Fe}_{3} \mathrm{O}_{4}$ nanoparticle-loaded hemoglobin, photosensitizer 
indocyanine green (ICG), and red blood cell membranes. When exposed to an acoustic field, the RBCM micromotors could convert the acoustic energy to movement at a velocity of up to $56.5 \mu \mathrm{m} \mathrm{s}^{-1}$ in biological media. The direction of the movement could be navigated by an external magnetic field. The motion characteristic and oxygen and photosensitizer-carrying ability of the RBCM micromotors make them promising agents for future PDT.

In a word, micro-/nanomotors could realize a novel "active PDT" with improved anticancer effect. The motion characteristic of active PDT may increase the utilization efficiency of oxygen and facilitate tumor hypoxia alleviation for enhanced PDT.

\subsubsection{Living Organism Oxygen Generators}

The employment of photosynthesis of microorganisms or chloroplast components extracted from green plants, is an emerging and promising approach to increase tumor oxygen concentration and improve PDT.

In the relatively early stage (since Year 2019), researchers utilized several kinds of photosynthetic microorganisms, including Chlorella [92], Cyanobacteria [93-98], and Spirulina [99], to achieve tumor oxygenation and PDT enhancement under visible light irradiation. After administration into the tumor-bearing mice, these microorganisms (usually modified with chemicals) showed prominent PDT efficiency enhancement via tumor hypoxia alleviation. The co-loaded artificial drugs [95], or innate chlorophyll released from the microorganism [99], served as photosensitizers. For instance, Zhou et al. constructed an autotrophic light-triggered green affording-oxygen engine (ALGAE) consisting of Chlorella and calcium alginate [92]. In vitro and in vivo results showed that the PDT efficiency was remarkably enhanced due to the photosynthesis of Chlorella. Moreover, the ALGAE may suppress tumor metastasis by downregulating the expression of vascular endothelial growth factor and HIF-1 $\alpha$, and upregulating the expression of epithelial cadherin. Calcium alginate protected the Chlorella from the phagocytosis of macrophage, allowing for its long period existence in the tumor site, and consequently highly efficient repetitive PDT treatments. However, these studies had to employ visible light to activate PDT, due to the requirement of the natural photosynthesis. This limits the application on deep-seated tumors.

More recently, microorganisms have been combined with UCNPs to move the activation light wavelength to the NIR range. Zhang et al. used Cyanobacteria as a living carrier for photosensitizer chlorin e6 conjugated UCNP to build a self-supplying oxygen PDT system [100]. Under NIR irradiation, this system relieved tumor hypoxia and boosted PDT efficiency both in vitro and in vivo. The recent progress on the photosynthetic microorganism-enhanced PDT also includes the combination of microorganism and perfluorocarbons for oxygen production and collection [101], and improvement of biocompatibility via biomineralization [102].

In addition to photosynthetic microorganisms, chloroplast components extracted from green plants were also used for tumor oxygen concentration elevation. Green plants rely on their chloroplasts to perform photosynthesis and generate oxygen. The oxygen generation by chloroplasts originates from the subtle Z-scheme structure containing the photosystem-I (PS-I) and photosystem-II (PS-II) located in thylakoid membranes (TM) of chloroplasts. The early research fused the thylakoid membrane with synthetic nanoparticles for efficient oxygen generation under $660 \mathrm{~nm}$ visible light irradiation [103]. In vivo studies demonstrated that the PDT efficiency was improved via photosynthesis-mediated tumor oxygenation. More recently, Cheng et al. prepared TM-decorated UCNPs (UCTM), realizing $980 \mathrm{~nm}$ NIR-activated PDT (Figure 8) [104]. The chlorophyll in the TM served as photosensitizer. Importantly, this outstanding design facilitated the synchronous and short-distance oxygen supply and ROS generation, making full use of the oxygen generated and improving PDT efficiency. 

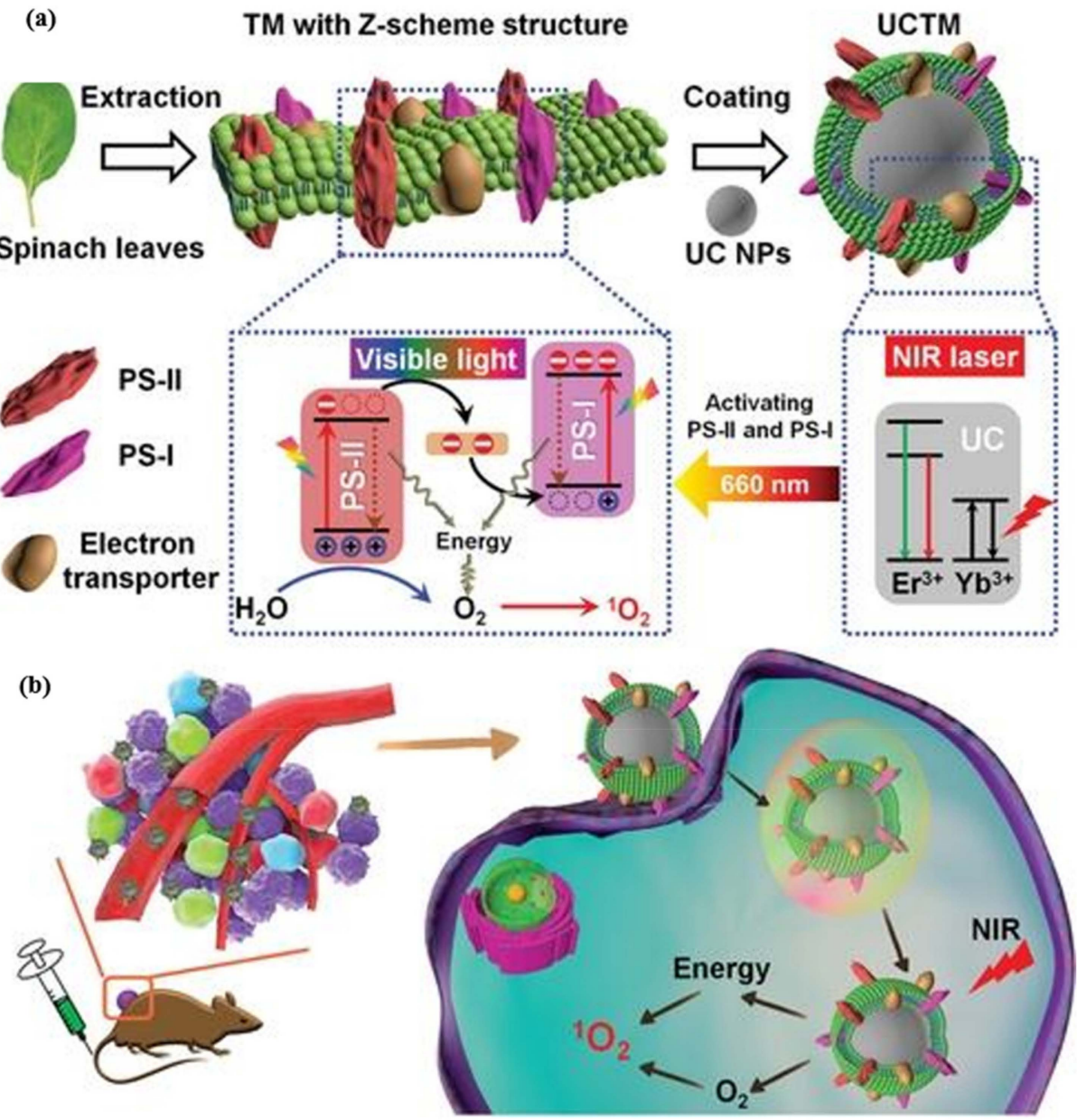

Figure 8. Illustration of thylakoid membrane-decorated upconversion nanoparticles (UCTM) for enhanced photodynamic efficacy against hypoxic tumors. (a) Preparation of UCTM and the corresponding electron transfer as well as oxygen and reactive oxygen species generation mechanism of UCTMs under near-infrared light irradiation. (b) the therapeutic process mediated by synchronous oxygen supply and reactive oxygen species generation under near-infrared light irradiation. Reprinted with permission from Ref. [104]. Copyright 2021 John Wiley and Sons.

In summary, as a new strategy for tumor hypoxia alleviation, biosynthetic living organism-based oxygen supplementation provides advantages over other hypoxia-addressing strategies, but also has its own shortcomings (Table 1). The advantages include: (1) Simultaneous oxygen supply and ROS production improving PDT efficiency. The synchronization of these two processes is important for the PDT efficiency. If oxygen is supplied early before or long past light-triggered ROS generation, these oxygen molecules would be remarkably consumed by the rapid-growing tumor cells instead of the PDT reaction. This renders the PDT ineffective. Using the biological photosynthesis, the oxygen generation and conversion of oxygen to ${ }^{1} \mathrm{O}_{2}$ happen at the same time when light is shone, promoting PDT efficiency. (2) Abundance of water in tumor tissues for oxygen formation via photosynthesis. Water is an essential component of living creatures, and exists in a large amount in tumors. This may facilitate oxygen production. However, this biological photosynthesis-based strategy also possesses disadvantages, including (1) Harsh TME lowering microorganism activity. As living organism or structures extracted from living organisms, the actuators of this strategy may confront difficulties in exerting or maintaining their photosynthetic activity in the harsh TME, including acidic $\mathrm{pH}$, overproduced $\mathrm{H}_{2} \mathrm{O}_{2}$, excessive glutathione, and temperature. For instance, the temperature of the tumor tissues may limit the photosynthetic activity of TMs extracted from green plants, since the activity of photosynthetic systems in 
green plants is very sensitive to temperature elevation [105,106]. (2) Large size hindering deep tumor penetration. The usual size of microorganisms is several micrometers. The large size might hinder the delivery of these microorganisms through the capillaries (the tiniest being 4-5 $\mathrm{mm}$ in diameter) to the tumor [107]. Moreover, in comparison with typical nanomaterials with diameters below $100 \mathrm{~nm}$, the microorganisms may have lower ability to penetrate to the hypoxic tumor core [108], resulting in insufficient tumor oxygenation and inadequate PDT efficacy. (3) Light wavelength hampering deep-seated tumor treatment. The wavelengths of the light for the photosynthesis lie in the range of visible light, which limits the deep-seated tumor treatment. To sum up, the biological photosynthesis strategy is a promising approach for hypoxic tumor PDT, and its performance could be further improved. The impact of these microorganisms on the human body, such as their effect on the immune system, could also be further explored.

\subsubsection{Light-Driven Water Splitting}

Chloroplasts in green plants absorb solar energy and transfer it to water to form oxygen. Inspired by this phenomenon, diverse water-splitting nanocomposites including organic, inorganic, or hybrid materials have been prepared for oxygen generation and PDT enhancement. This strategy has unique advantages including synchronous activation of oxygen supply and ROS generation, and abundance of water in the human body for oxygen production.

$\mathrm{C}_{5} \mathrm{~N}_{2}$ nanoparticles [109], $\mathrm{C}_{3} \mathrm{~N}_{4}$ [110,111], tungsten nitride [112], carbon nanodot [113], graphdiyne oxide [114], iron disulfide $\left(\mathrm{FeS}_{2}\right)$ [115], cobalt phytate [116], etc., have been used in the water-splitting strategy. $\mathrm{C}_{3} \mathrm{~N}_{4}$-related materials have been intensively studied for the enhancement of PDT via water splitting-mediated oxygen generation. Recent progress on $\mathrm{C}_{3} \mathrm{~N}_{4}$-related nanostructures include the enhancement of light absorption at 700-900 nm optical transparency window [117] and utilization of two-photon excitation [118], which facilitate deep-seated tumor treatment.

\subsubsection{Modification of Tumor Blood Circulation}

It was reported that pre-administration of heparin, a clinically utilized anticoagulant, could temporarily prevent vessels from shutting down during PDT treatment, enhancing oxygen supply and PDT efficiency [119]. The oxygenation also improved light delivery because it maintained the tissue optical properties during the PDT treatment procedure. It was also demonstrated that a warm water bath $\left(43^{\circ} \mathrm{C}\right)$ could improve the blood flow velocity and increase tumor oxygen level, boosting PDT [120].

\subsubsection{Tumor $\mathrm{H}_{2} \mathrm{O}_{2}$ Decomposition}

The level of $\mathrm{H}_{2} \mathrm{O}_{2}$ in the tumor is higher than normal tissues owing to the higher $\mathrm{H}_{2} \mathrm{O}_{2}$ generation rate of cancer cells (up to $0.5 \mathrm{nmol} / 10^{4}$ cells $/ \mathrm{h}$ ) $[121,122]$. The overproduced $\mathrm{H}_{2} \mathrm{O}_{2}$ is related to the angiogenesis, proliferation and metastasis of tumors [3]. Therefore, decomposing the tumor endogenous $\mathrm{H}_{2} \mathrm{O}_{2}$ to produce oxygen is a promising approach for tumor hypoxia alleviation and PDT enhancement. This approach has been intensively studied, and a wide variety of nanocomposites capable of promoting $\mathrm{H}_{2} \mathrm{O}_{2}$ decomposition were fabricated and demonstrated effective for PDT enhancement. The materials that could accelerate $\mathrm{H}_{2} \mathrm{O}_{2}$ decomposition mainly include metal-based materials and catalase.

Recently, the employment of metal-based materials to promote the decomposition of tumor endogenous $\mathrm{H}_{2} \mathrm{O}_{2}$ to generate oxygen has attracted increasing attention. Titanium dioxide-modified palladium (Pd) nanosheets [123], Pd nanoparticles [124], defective cobalt (Co) hydroxide [125], $\mathrm{Co}_{3} \mathrm{O}_{4}$ nanoparticles [126], iridium (Ir) oxide [127,128], cerium (Ce) oxide nanoparticles [129,130], platinum (Pt) nanozyme [131,132], gold (Au) nanoclusters [133], iron (Fe)-based materials [134-138], etc. have been used to accelerate the decomposition of $\mathrm{H}_{2} \mathrm{O}_{2}$ to generate oxygen. For instance, recently, $\mathrm{Xu}$ et al. developed a defective cobalt hydroxide-based nanoagent for hypoxia-ameliorating photothermal-enhanced photodynamic therapy [125]. They converted cobalt hydroxide into black and defect-abundant 
nanosheets via oxidation, extending the absorbance range to NIR-I (750-980 nm), and achieving high photothermal conversion efficiency and enhanced $\mathrm{H}_{2} \mathrm{O}_{2}$ decomposition activity. The defective cobalt hydroxide nanosheets were further linked to chlorin e6 to form a nanoagent denoted as BCS-Ce6. In vivo experiments showed that BCS-Ce6 could almost eliminate the implanted tumors in mice. This research provided an innovative approach to produce novel therapeutic nanostructures for TME-modulating phototherapy.

Among the metal-based materials for generating oxygen through $\mathrm{H}_{2} \mathrm{O}_{2}$ decomposition, $\mathrm{MnO}_{2}$ is a widely studied material [139-149]. $\mathrm{MnO}_{2}$ could produce oxygen and $\mathrm{Mn}^{2+}$ at acidic $\mathrm{pH}$, particularly in the presence of $\mathrm{H}_{2} \mathrm{O}_{2}$. It was also found that $\mathrm{MnO}_{2}$ could decrease the intratumoral glutathione level. These properties make $\mathrm{MnO}_{2}$ highly responsive to the TME featured with acidic $\mathrm{pH}$, overproduced $\mathrm{H}_{2} \mathrm{O}_{2}$ and abundant glutathione, which is beneficial for tumor selectivity. Moreover, the generated $\mathrm{Mn}^{2+}$ can enhance T1-weighted magnetic resonance imaging, allowing for imaging-guided tumor therapy. However, the generated $\mathrm{Mn}^{2+}$ may elicit toxicity if its concentration is high.

Catalase is an important enzyme in the human body. It catalyzes the transformation of $\mathrm{H}_{2} \mathrm{O}_{2}$ to water and oxygen. It is widely used in the construction of nanosystems for hypoxic tumor PDT [150-154]. For instance, catalase was co-encapsulated with a photosensitizer MBDP and a chemotherapeutic drug doxorubicin to obtain FA-L@MD@CAT [155]. The FAL@MD@CAT could catalyze tumor endogenous $\mathrm{H}_{2} \mathrm{O}_{2}$ to generate oxygen, enhancing cancer chemo-photodynamic therapy. Importantly, examinations on tumor-bearing mice showed that FA-L@MD@CAT helped to reverse M2-polarized tumor associated macrophages (TAMs), and increased cytotoxic T lymphocyte (CTL) levels and CD8+ CTL/regulatory T cell (Treg) ratio. This suggested that FA-L@MD@CAT could trigger immunogenic cell death (ICD) to induce CTL infiltration into tumors, and reverse immunosuppressive TME by addressing tumor hypoxia. This research provided a promising nanoplatform for enhanced cancer chemo-photodynamic therapy, and highlighted the important role hypoxia-addressing PDT may play in the enhancement of antitumor immune response. Recently, genetically modified Escherichia coli (E. coli) with overexpressed human catalase was combined with photosensitizers such as chlorin e6 [156] and black phosphorus quantum dots [157], and enhanced PDT by catalyzing $\mathrm{H}_{2} \mathrm{O}_{2}$ into $\mathrm{O}_{2}$ in the tumor site.

The metal-based materials and catalase have their distinct strengths and limitations for tumor $\mathrm{H}_{2} \mathrm{O}_{2}$ decomposition (Table 2). Metal-based materials (for instance, $\mathrm{Co}_{3} \mathrm{O}_{4}$ [126]) may have better stability than natural catalase when they are exposed to solutions with different $\mathrm{pH}$ values and temperatures. However, the activity of metal-based materials is lower than catalase [158], and the generated metal ions may cause toxicity if their concentrations are high. In contrast, catalase, as a biological catalyst, has higher activity than metal-based materials. Nevertheless, the enzymatic activity of catalase is easily compromised in harsh environments such as improper $\mathrm{pH}$ values and temperatures. The activity may also be hampered by chemical modification during preparation of nanocomposites, since the enzymatic activity relies on the correct folding of the peptides [159].

Table 2. A summary of the strengths and shortcomings of different materials for tumor $\mathrm{H}_{2} \mathrm{O}_{2}$ decomposition.

\begin{tabular}{ccc}
\hline $\begin{array}{c}\text { Materials for Tumor } \mathrm{H}_{\mathbf{2}} \mathrm{O}_{2} \\
\text { Decomposition }\end{array}$ & Strengths & Shortcomings \\
\hline Metal-based materials & $\begin{array}{c}\text { Superior stability in } \\
\text { environments with different } \\
\text { pH values and temperatures }\end{array}$ & $\begin{array}{c}\text { Lower activity than catalase, } \\
\text { safety concern arisen from } \\
\text { metal ions }\end{array}$ \\
\hline Catalase & High activity as a biological \\
catalyst & $\begin{array}{c}\text { Low stability in environments } \\
\text { with different pH values and } \\
\text { temperatures }\end{array}$ \\
\hline
\end{tabular}


The tumor $\mathrm{H}_{2} \mathrm{O}_{2}$ decomposition strategy has distinct advantage of high tumor specificity, as $\mathrm{H}_{2} \mathrm{O}_{2}$ is overproduced in the tumor site. However, the efficiency of this strategy is limited by the low $\mathrm{H}_{2} \mathrm{O}_{2}$ level in the tumor $(50 \sim 100 \mu \mathrm{M})$ [160].

\subsubsection{Oxygen Delivery}

Because of the oxygen affinity of hemoglobin, perfluorocarbon, or metal-organic frameworks, these materials can be used to efficiently transport oxygen to the tumor site and boost PDT. The merits and shortcomings of these materials are listed in Table 3.

Table 3. A summary of the representative materials, strengths, and shortcomings of different oxygen delivery approaches for hypoxic tumor PDT. ${ }^{1} \mathrm{O}_{2}$, singlet oxygen. ZIF-90, zeolitic imidazolate framework-90.

\begin{tabular}{cccc}
\hline Strategy & $\begin{array}{c}\text { Representative } \\
\text { Materials }\end{array}$ & Strengths & Shortcomings \\
\hline Hemoglobin & $\begin{array}{c}\text { Modified } \\
\text { hemoglobin, red } \\
\text { blood cells }\end{array}$ & $\begin{array}{c}\text { Tumor-specific oxygen } \\
\text { release owing to Bohr } \\
\text { effect, ability of the red } \\
\text { blood cell membrane to } \\
\text { escape from immune } \\
\text { clearance }\end{array}$ & $\begin{array}{c}\text { Low oxygen loading } \\
\text { capacity, safety concern }\end{array}$ \\
\hline Perfluorocarbon & $\begin{array}{c}\text { Perfluorohexane, } \\
\text { perfluorooctyl } \\
\text { bromide, perfluoro- } \\
\text { 15-crown-5-ether, } \\
\text { perfluorotributy- } \\
\text { lamine }\end{array}$ & $\begin{array}{c}\text { High oxygen loading } \\
\text { capacity, FDA-approved } \\
\text { materials such as } \\
\text { perfluorohexane, } \\
\text { increased }{ }^{1} \text { O }_{2} \text { lifetime }\end{array}$ & $\begin{array}{c}\text { Relatively weak } \\
\text { tumor-specific oxygen } \\
\text { release }\end{array}$ \\
\hline $\begin{array}{c}\text { Metal-organic } \\
\text { frameworks }\end{array}$ & UiO-66, ZIF-90 & $\begin{array}{c}\text { Multifunctionality, high } \\
\text { oxygen loading capacity }\end{array}$ & $\begin{array}{c}\text { Potential toxicity arisen } \\
\text { from metal ions }\end{array}$ \\
\hline
\end{tabular}

Hemoglobin and Red Blood Cell-Based Oxygen Carriers

Hemoglobin is the natural oxygen carrier residing in red blood cells. Each hemoglobin molecule can bind up to four oxygen molecules. Owing to the oxygen-carrying ability of hemoglobin, a number of hemoglobin-based nanosystems have been constructed to transport oxygen to the tumor site and enhance PDT. As a natural protein for oxygen transportation in living organisms, hemoglobin might provide the advantage that the transported oxygen can be easily released in $\mathrm{H}^{+}$and carbon-dioxide-rich TME (Bohr effect) [161]. Despite its great potential, free hemoglobin faces limitations such as potential toxic effect after autoxidation. This autoxidation could be exacerbated in the $\mathrm{H}_{2} \mathrm{O}_{2}$-rich TME [162]. It has been reported that free hemoglobin in circulation may elicit side effects such as kidney tubule damage [163]. Therefore, hemoglobin is often further engineered for hypoxic tumor PDT through chemical conjugation or physical encapsulation [164-167].

For example, recently a paramagnetic nanostructure consisting of hemoglobin, $\mathrm{Gd}$, and PEGylated chlorin e6, was prepared using a non-toxic hemoglobin-mediated biomimetic synthesis method [168]. Interestingly, hemoglobin functioned as a biological template, stabilizer for the nanoparticle formation, and substrate for the loading of chlorin e6 in the synthesis process, and maintained its ability to bind and carry oxygen. In vitro and in vivo experiments showed that the nanostructure enhanced PDT efficiency by replenishing tumor hypoxia, and could be guided by magnetic resonance imaging. The unique eco-friendly and non-toxic preparation method and the potent PDT efficiency make this nanostructure a promising nanomedicine for future application.

Hemoglobin-based nanosystems are frequently encapsulated with red blood cell membranes to increase their biocompatibility and ability to escape from elimination by immune system [169]. In addition, red blood cells can be linked with photosensitizers and other substance to realize hypoxia-alleviating PDT. For instance, Wang et al. installed photosensitizer 
(rose bengal) and tumor-targeting RGD peptide functionalized upconversion nanoparticles onto the surface of indocyanine green-loaded red blood cells, and obtained RBCp. The RBCp enhanced PDT efficiency and showed great potential for second near-infrared window fluorescence imaging-guided tumor surgery and photodynamic therapy [170].

\section{Perfluorocarbon-Based Oxygen Carriers}

Perfluorocarbons are synthetic molecules consisting of carbon and fluorine atoms. They have extraordinary oxygen solubility because of the high electronegativity of fluorine [11]. At normal atmospheric pressure, perfluorocarbons can load about twice the amount of oxygen as blood can [171]. Moreover, perfluorocarbons exhibited excellent biocompatibility. For instance, perfluorohexane is approved by FDA. It has also been found that the lifetime of ROS can be extended in perfluorohexane [172] or perfluorotributylamine (PFTBA) [173], which enhanced PDT efficiency.

Oxygen delivery by perfluorocarbons has been extensively studied. A variety of perfluorocarbons have been used for the preparation of nanoformulations to achieve oxygen-supplementing PDT, including perfluorohexane [174,175], perfluorooctyl bromide (PFOB) [176], perfluoro-15-crown-5-ether [177], PFTBA [178], etc. Recently, a PFOB-based nanostructure was reported to combat liver metastasis of colon cancer [179]. PFOB was dispersed into porphyrin grafted lipid (PGL) nanoparticles (NPs), and then oxygen was loaded to obtain $\mathrm{O}_{2} @$ PFOB@PGL NPs. The $\mathrm{O}_{2} @ P F O B @ P G L$ NPs achieved very high loading content for both porphyrin and PFOB. It served as a prominent oxygen reservoir, and remarkably relieved tumor hypoxia. The $\mathrm{O}_{2} @ P F O B @ P G L$ NPs not only dramatically improved PDT efficiency to eliminate the primary tumor, but also addressed tumor hypoxia to inhibit hypoxia-promoted colorectal cancer liver metastasis via decreasing COX-2 expres-

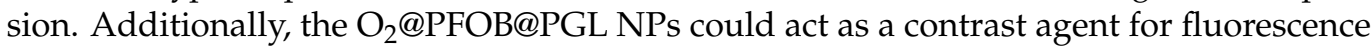
and computed tomography imaging, facilitating bimodal imaging-guided PDT. To sum up, this nanostructure provides a promising strategy to combat colon cancer and to inhibit metastasis by replenishing tumor hypoxia.

\section{Metal-Organic Frameworks}

Recently, metal-organic frameworks (MOFs) were used to transport oxygen and enhance PDT against hypoxic tumors. MOFs are materials that are prepared via coordinating metal ions with organic linkers. Owing to the large surface area and uniform pore size, MOFs have excellent ability of gas storage and separation. Gao et al. used the MOF UiO-66 as oxygen reservoir for enhanced PDT against hypoxic tumors [180]. The UiO-66 was combined with the photosensitizer ICG, and encapsulated inside red blood cell membranes to obtain a nanoplatform $\mathrm{O}_{2} @ \mathrm{UiO}-66 @ \mathrm{ICG} @ \mathrm{RBC}$. The oxygen transportation by the UiO-66 prominently boosted the PDT efficacy. Moreover, the red blood cell coating endowed the $\mathrm{O}_{2} @$ UiO-66@ICG@RBC ability to escape from elimination by immune systems, further improving antitumor effect. Xie et al. used another MOF material, Zeolitic imidazolate framework-90 (ZIF-90), as oxygen reservoir to improve PDT efficacy [181]. They prepared a multifunctional system UC@mSiO ${ }_{2}$-RB@ZIF- ${ }_{2}$-DOX-PEGFA (URODF) for combined PDT and chemotherapy. The upconversion nanoparticles (UC) could convert NIR irradiation to ultraviolet/visible light and activate the photosensitizer Rose Bengal (RB) loaded on the mesoporous silica shell $\left(\mathrm{mSiO}_{2}\right)$. Doxorubicin (DOX) and $\mathrm{NH}_{2}$-PEG modified folic acid (PEGFA) were included for chemotherapy. In vitro and in vivo results indicated the outstanding therapeutic outcome of URODF.

The inherent multifunctionality confers MOFs unique advantage over other oxygen carriers. For instance, MOFs are good carriers for photosensitizers and chemotherapeutic drugs. However, the metal ions might elicit safety concerns.

\section{Emerging Trends and Outlook}

Oxygen-independent phototherapy, oxygen-economizing PDT, and oxygen-suppleme nting PDT have their unique advantages and limitations, as summarized in Table 4 . There- 
fore, creative combination of these strategies might bridge advantages and eliminate shortcomings, advancing PDT treatment efficacy. Antitumor efficiency is an important index for evaluating hypoxia-addressing strategies. However, the antitumor efficiency depends on multiple factors, including what photosensitizer is used, the loading efficiency of photosensitizer, light irradiation intensity, light irradiation dose, etc. Therefore, it seems impossible to conclude which hypoxia-addressing strategy has highest antitumor efficiency. However, the antitumor efficiency of each research, that is, the efficiency of each special micro/nanosystem, can be roughly compared according to the volume change of mouse tumors after treatment with the micro/nanosystems. Nowadays, generally speaking, decelerated tumor growth in comparison with the control group can be considered effective for tumor treatment, but not satisfactory; decrease in tumor volume till final complete elimination of the tumor in 1 or 2 weeks may represent high antitumor efficiency; complete tumor elimination within 10 minutes, which was realized by the photogenerated hole therapy based on SA-TCPP as introduced in this review, can be viewed as exceedingly high antitumor efficiency.

Table 4. An overview of strategies for modulating tumor hypoxia in photodynamic therapy. ROS, reactive oxygen species. ${ }^{1} \mathrm{O}_{2}$, singlet oxygen. ATP, adenosine triphosphate.

\begin{tabular}{ccc}
\hline Strategy & Strengths & Shortcomings \\
\hline $\begin{array}{c}\text { Oxygen-independent } \\
\text { phototherapy }\end{array}$ & $\begin{array}{c}\text { Generation of ROS with } \\
\text { stronger oxidation } \\
\text { performance than }{ }^{1} \mathrm{O}_{2}\end{array}$ & $\begin{array}{c}\text { Hypoxia-related issues such } \\
\text { as drug-resistant gene } \\
\text { expression unresolved }\end{array}$ \\
\hline Oxygen-economizing PDT & $\begin{array}{c}\text { Synergetic ATP production } \\
\text { inhibition }\end{array}$ & $\begin{array}{c}\text { Maximum efficiency limited } \\
\text { by the existing oxygen content }\end{array}$ \\
\hline Oxygen-supplementing PDT & $\begin{array}{c}\text { Hypoxia-related issues such } \\
\text { as drug-resistant gene } \\
\text { expression attenuated }\end{array}$ & $\begin{array}{c}\text { Difficulty in achieving both } \\
\text { continuous and efficient } \\
\text { oxygen supply }\end{array}$ \\
\hline
\end{tabular}

It is noteworthy that by addressing hypoxia, remarkable achievements on cancer treatment have been made, including potent efficacy (tumor elimination within $10 \mathrm{~min}$ ), inhibition effect on tumor metastasis, and promotion of antitumor immune response. With these encouraging achievements, we believe that considerable improvement of cancer treatment outcome could be realized by advanced hypoxia-addressing materials. Meanwhile, the continuous emergence of creative strategies, such as the employment of micro/nanomotors, microorganism-mediated oxygen generation, and utilization of ROS with stronger oxidation performance than ${ }^{1} \mathrm{O}_{2}$ (e.g., $\mathrm{OH}$ ), will inspire more novel and useful strategies for PDT against hypoxic tumors.

We could also conclude that the temporal and spatial control is important for the improvement of PDT efficiency. It is noteworthy that synchronizing oxygen supply and photosensitizer activation, shortening the distance between oxygen and photosensitizer molecules, shortening the distance between ROS and biomolecules such as mitochondria DNA molecules, and enlarging the diffusion distances of oxygen and photosensitizers in tumor tissues, can improve PDT efficacy. The extremely short lifetime (less than $200 \mathrm{~ns}$ ) and diffusion distance (about $20 \mathrm{~nm}$ ) of ROS severely limit PDT efficiency. Therefore, increasing the lifetime of ROS could lead to enhancement of PDT.

Despite the bright prospect of hypoxia-addressing PDT, challenges for the development remain. For example, the effect of hypoxia amelioration on the tumor metastasis inhibition and antitumor immunity needs to be further studied and improved. Although hypoxia-activable chemotherapeutic drugs have been combined with photosensitizers, chemicals that can only show toxicity in the presence of both hypoxia and light, remain to be investigated. 


\begin{abstract}
Author Contributions: Conceptualization, L.H. and Z.H.; writing-original draft preparation, L.H., J.L., Y.L. (Yali Luo) and C.Z.; writing-review and editing, T.G., S.O. and Y.L. (Yaohang Long); supervision, Z.H.; funding acquisition, L.H. and Z.H. All authors have read and agreed to the published version of the manuscript.

Funding: This work was funded by the National Natural Science Foundation of China (32160224, 12132006), the Guizhou Provincial Natural Science Foundation (2021-5637, 2019-2787, ZK2021-029, 2016-5676), the Excellent Young Talents Plan of Guizhou Medical University (2021-101), the Science and Technology Fund Project of Guizhou Provincial Health Commission (gzwkj2022-228) and the High-Level Talent Initiation Project of Guizhou Medical University (J[2021] 029).
\end{abstract}

Institutional Review Board Statement: Not applicable.

Informed Consent Statement: Not applicable.

Data Availability Statement: Not applicable.

Conflicts of Interest: The authors declare no conflict of interest.

\title{
References
}

1. Liu, R.; Gao, Y.; Liu, N.; Suo, Y. Nanoparticles loading porphyrin sensitizers in improvement of photodynamic therapy for ovarian cancer. Photodiagn. Photodyn. Ther. 2021, 33, 102156. [CrossRef]

2. Montaseri, H.; Kruger, C.; Abrahamse, H. Inorganic nanoparticles applied for active targeted photodynamic therapy of breast cancer. Pharmaceutics 2021, 13, 296. [CrossRef] [PubMed]

3. Dang, J.; He, H.; Chen, D.; Yin, L. Manipulating tumor hypoxia toward enhanced photodynamic therapy (PDT). Biomater. Sci. 2017, 5, 1500-1511. [CrossRef] [PubMed]

4. Moulder, J.E.; Rockwell, S. Tumor hypoxia: Its impact on cancer therapy. Cancer Metastasis Rev. 1987, 5, 313-341. [CrossRef] [PubMed]

5. Sun, Y.; Zhao, D.; Wang, G.; Wang, Y.; Cao, L.; Sun, J.; Jiang, Q.; He, Z. Recent progress of hypoxia-modulated multifunctional nanomedicines to enhance photodynamic therapy: Opportunities, challenges, and future development. Acta Pharm. Sin. B 2020, 10, 1382-1396. [CrossRef] [PubMed]

6. Hong, L.; Pliss, A.M.; Zhan, Y.; Zheng, W.; Xia, J.; Liu, L.; Qu, J.; Prasad, P.N. Perfluoropolyether nanoemulsion encapsulating chlorin e6 for sonodynamic and photodynamic therapy of hypoxic tumor. Nanomaterials 2020, 10, 2058. [CrossRef] [PubMed]

7. Atkuri, K.R.; Herzenberg, L.A.; Niemi, A.-K.; Cowan, T. Importance of culturing primary lymphocytes at physiological oxygen levels. Proc. Natl. Acad. Sci. USA 2007, 104, 4547-4552. [CrossRef]

8. Broekgaarden, M.; Weijer, R.; Van Wijk, A.C.; Cox, R.C.; Egmond, M.R.; Hoebe, R.; Van Gulik, T.M.; Heger, M. Photodynamic therapy with liposomal zinc phthalocyanine and tirapazamine increases tumor cell death via DNA damage. J. Biomed. Nanotechnol. 2017, 13, 204-220. [CrossRef] [PubMed]

9. He, Z.; Dai, Y.; Li, X.; Guo, D.; Liu, Y.; Huang, X.; Jiang, J.; Wang, S.; Zhu, G.; Zhang, F.; et al. Hybrid nanomedicine fabricated from photosensitizer-terminated metal-organic framework nanoparticles for photodynamic therapy and hypoxia-activated cascade chemotherapy. Small 2019, 15, e1804131. [CrossRef]

10. Li, X.; Kwon, N.; Guo, T.; Liu, Z.; Yoon, J. Innovative strategies for hypoxic-tumor photodynamic therapy. Angew. Chem. Int. Ed. 2018, 57, 11522-11531. [CrossRef]

11. Pucelik, B.; Sułek, A.; Barzowska, A.; Dabrowski, J.M. Recent advances in strategies for overcoming hypoxia in photodynamic therapy of cancer. Cancer Lett. 2020, 492, 116-135. [CrossRef]

12. Sara, R.; Iwona, T.D.; Eugene, Y.K.; Marrison, S.T.; Van Thuc, V. Hypoxia and radiation therapy: Past history, ongoing re-search, and future promise. Curr. Mol. Med. 2009, 9, 442-458.

13. Chen, Q.; Huang, Z.; Chen, H.; Shapiro, H.; Beckers, J.; Hetzel, F.W. Improvement of tumor response by manipulation of tumor oxygenation during photodynamic therapy. Photochem. Photobiol. 2002, 76, 197-203. [CrossRef]

14. Zhang, Z.; Wang, L.; Liu, W.; Yan, Z.; Zhu, Y.; Zhou, S.; Guan, S. Photogenerated-hole-induced rapid elimination of solid tumors by the supramolecular porphyrin photocatalyst. Natl. Sci. Rev. 2021, 8, 155. [CrossRef]

15. Banerjee, S.; Pillai, S.C.; Falaras, P.; O'Shea, K.E.; Byrne, J.A.; Dionysiou, D.D. New insights into the mechanism of visible light photocatalysis. J. Phys. Chem. Lett. 2014, 5, 2543-2554. [CrossRef]

16. Zang, Y.; Wei, Y.; Shi, Y.; Chen, Q.; Xing, D. Chemo/photoacoustic dual therapy with mRNA-triggered DOX release and photoinduced shockwave based on a DNA-gold nanoplatform. Small 2016, 12, 756-769. [CrossRef] [PubMed]

17. Zhang, R.; Zeng, Q.; Li, X.; Xing, D.; Zhang, T. Versatile gadolinium(III)-phthalocyaninate photoagent for MR/PA imag-ingguided parallel photocavitation and photodynamic oxidation at single-laser irradiation. Biomaterials 2021, 275, 120993. [CrossRef] [PubMed]

18. Yue, X.; Yanez, C.O.; Yao, S.; Belfield, K.D. Selective cell death by photochemically induced pH Imbalance in cancer cells. J. Am. Chem. Soc. 2013, 135, 2112-2115. [CrossRef] 
19. Fadhel, A.A.; Yue, X.; Zadeh, E.H.G.; Bondar, M.V.; Belfield, K.D. Pegylated and nanoparticle-conjugated sulfonium salt photo triggers necrotic cell death. Int. J. Nanomed. 2016, 11, 6161-6168. [CrossRef]

20. He, L.; Zhang, M.-F.; Pan, Z.-Y.; Wang, K.-N.; Zhao, Z.-J.; Li, Y.; Mao, Z.-W. A mitochondria-targeted iridium(iii)-based photoacid generator induces dual-mode photodynamic damage within cancer cells. Chem. Commun. 2019, 55, 10472-10475. [CrossRef] [PubMed]

21. Tian, N.; Sun, W.; Feng, Y.; Guo, X.; Lu, J.; Li, C.; Hou, Y.; Wang, X.; Zhou, Q. Chloromethyl-modified Ru(ii) complexes enabling large $\mathrm{pH}$ jumps at low concentrations through photoinduced hydrolysis. Chem. Sci. 2019, 10, 9949-9953. [CrossRef]

22. Zhang, L.; Fan, Y.; Yang, Z.; Yang, M.; Wong, C.Y. NIR-II-driven and glutathione depletion-enhanced hypoxia-irrelevant free radical nanogenerator for combined cancer therapy. J. Nanobiotechnol. 2021, 19, 265. [CrossRef]

23. Xia, R.; Zheng, X.; Hu, X.; Liu, S.; Xie, Z. Photothermal controlled gneration of alkyl radical from organic nanoparticles for tumor treatment. ACS Appl. Mater. Interfaces 2019, 11, 5782-5790. [CrossRef]

24. Wu, Q.; Han, J.; Li, C.; Sun, T.; Xie, Z. Photothermal Therapy Combined with Light-Induced Generation of Alkyl Radicals for Enhanced Efficacy of Tumor Treatment. ACS Appl. Polym. Mater. 2020, 2, 4188-4194. [CrossRef]

25. Wu, S.; Liu, X.; Ren, J.; Qu, X. Glutathione depletion in a benign manner by MoS 2 -based nanoflowers for enhanced hypox-iairrelevant free-radical-based cancer therapy. Small 2019, 15, 1904870. [CrossRef] [PubMed]

26. Zhou, L.; Zhao, J.; Chen, Y.; Zheng, Y.; Li, J.; Zhao, J.; Zhang, J.; Liu, Y.; Liu, X.; Wang, S. MoS 2 -ALG-Fe/GOx hydrogel with Fenton catalytic activity for combined cancer photothermal, starvation, and chemodynamic therapy. Colloids Surf. B Biointerfaces 2020, 195, 111243. [CrossRef] [PubMed]

27. Hu, P.; Wu, T.; Fan, W.; Chen, L.; Liu, Y.; Ni, D.; Bu, W.; Shi, J. Near infrared-assisted Fenton reaction for tumor-specific and mitochondrial DNA-targeted photochemotherapy. Biomaterials 2017, 141, 86-95. [CrossRef]

28. Dong, S.M.; Xu, J.T.; Jia, T.; Xu, M.S.; Zhong, C.N.; Yang, G.X.; Li, J.R.; Yang, D.; He, F.; Gai, S.L.; et al. Upcon-version-mediated $\mathrm{ZnFe}_{2} \mathrm{O}_{4}$ nanoplatform for NIR-enhanced chemodynamic and photodynamic therapy. Chem. Sci. 2019, 10, 4259-4271. [CrossRef]

29. Giannakis, S.; López, M.I.P.; Spuhler, D.; Pérez, J.A.S.; Fernandez-Ibañez, P.; Pulgarin, C. Solar disinfection is an augmentable, in situ -generated photo-Fenton reaction-Part 1: A review of the mechanisms and the fundamental aspects of the process. Appl. Catal. B Environ. 2016, 199, 199-223. [CrossRef]

30. Xiao, S.; Lu, Y.; Feng, M.; Dong, M.; Cao, Z.; Zhang, X.; Chen, Y.; Liu, J. Multifunctional FeS 2 theranostic nanoparticles for photothermal-enhanced chemodynamic/photodynamic cancer therapy and photoacoustic imaging. Chem. Eng. J. 2020, 396, 125294. [CrossRef]

31. Lu, J.; Yang, J.; Yang, D.; Hu, S.; Sun, Q.; Yang, G.; Gai, S.; Wang, Z.; Yang, P. CuFeSe 2 -based thermo-responsive multifunctional nanomaterial initiated by a single NIR light for hypoxic cancer therapy. J. Mat. Chem. B 2021, 9, 336-348. [CrossRef]

32. Dong, S.; Dong, Y.; Jia, T.; Zhang, F.; Wang, Z.; Feng, L.; Sun, Q.; Gai, S.; Yang, P. Sequential catalytic, magnetic targeting nanoplatform for synergistic photothermal and NIR-enhanced chemodynamic therapy. Chem. Mater. 2020, 32, 9868-9881. [CrossRef]

33. Pan, C.; Ou, M.; Cheng, Q.; Zhou, Y.; Yu, Y.; Li, Z.; Zhang, F.; Xia, D.; Mei, L.; Ji, X. Z-Scheme heterojunction functionalized pyrite nanosheets for modulating tumor microenvironment and strengthening photo/chemodynamic therapeutic effects. Adv. Funct. Mater. 2020, 30, 1906466. [CrossRef]

34. Bao, W.; Liu, M.; Meng, J.; Liu, S.; Wang, S.; Jia, R.; Wang, Y.; Ma, G.; Wei, W.; Tian, Z. MOFs-based nanoagent enables dual mitochondrial damage in synergistic antitumor therapy via oxidative stress and calcium overload. Nat. Commun. 2021, 12, 1-17. [CrossRef] [PubMed]

35. Shen, J.; Yu, H.; Shu, Y.; Ma, M.; Chen, H. A robust ROS generation strategy for enhanced chemodynamic/photodynamic therapy via $\mathrm{H}_{2} \mathrm{O}_{2} / \mathrm{O}_{2}$ self-supply and $\mathrm{Ca}^{2+}$ overloading. Adv. Funct. Mater. 2021, in press. [CrossRef]

36. Meng, X.; Zhang, X.; Liu, M.; Cai, B.; He, N.; Wang, Z. Fenton reaction-based nanomedicine in cancer chemodynamic and synergistic therapy. Appl. Mater. Today 2020, 21, 100864. [CrossRef]

37. Ma, B.; Wang, S.; Liu, F.; Zhang, S.; Duan, J.; Li, Z.; Kong, Y.; Sang, Y.; Liu, H.; Bu, W.; et al. Self-assembled copper-amino acid nanoparticles for in situ glutathione "AND" $\mathrm{H}_{2} \mathrm{O}_{2}$ sequentially triggered chemodynamic therapy. J. Am. Chem. Soc. 2019, 141, 849-857. [CrossRef]

38. Wang, X.; Zhong, X.; Lei, H.; Geng, Y.; Zhao, Q.; Gong, F.; Yang, Z.; Dong, Z.; Liu, Z.; Cheng, L. Hollow Cu 2 Se nanozymes for tumor photothermal-catalytic therapy. Chem. Mater. 2019, 31, 6174-6186. [CrossRef]

39. Liu, W.; Chen, L.; Wang, L.; Xie, Z.G. Photoactive metal-organic framework@porous organic polymer nanocomposites with pH-triggered type I photodynamic therapy. Adv. Mater. Interfaces 2020, 7, 2000504. [CrossRef]

40. Zhen, W.; Liu, Y.; Jia, X.; Wu, L.; Wang, C.; Jiang, X. Reductive surfactant-assisted one-step fabrication of a BiOI/BiOIO3 heterojunction biophotocatalyst for enhanced photodynamic theranostics overcoming tumor hypoxia. Nanoscale Horizons 2019, 4, 720-726. [CrossRef]

41. Chen, D.P.; Wang, Z.C.; Dai, H.M.; Lv, X.Y.; Ma, Q.L.; Yang, D.P.; Shao, J.J.; Xu, Z.G.; Dong, X.C. Boosting $\mathrm{O}_{2}$-photogeneration via promoting intersystem-crossing and electron-donating efficiency of Aza-BODIPY-based nanoplatforms for hypoxic-tumor photodynamic therapy. Small Methods 2020, 7, 2000013. [CrossRef] 
42. Belik, A.; Rybkin, A.; Goryachev, N.; Sadkov, A.; Filatova, N.; Buyanovskaya, A.; Talanova, V.; Klemenkova, Z.; Romanova, V.; Koifman, M.; et al. Nanoparticles of water-soluble dyads based on amino acid fullerene C60 derivatives and pyropheophorbide: Synthesis, photophysical properties, and photodynamic activity. Spectrochim. Acta Part A Mol. Biomol. Spectrosc. 2021, $260,119885$. [CrossRef] [PubMed]

43. Qiu, M.; Wang, D.; Huang, H.; Yin, T.; Bao, W.; Zhang, B.; Xie, Z.; Xie, N.; Wu, Z.; Ge, C.; et al. A regioselectively oxidized 2D $\mathrm{Bi} / \mathrm{BiOx}$ lateral nano-heterostructure for hypoxic photodynamic therapy. Adv. Mater. 2021, 33, 2102562. [CrossRef]

44. Tian, J.W.; Teng, M.Z.; Song, M.; Li, Z.J.; Zhang, X.Y.; Xu, Y.Q. A feasible molecular engineering for bright II-conjugation free radical photosensitizers with aggregation-induced emission. Dyes Pigment. 2021, 194, 109651. [CrossRef]

45. Zhao, Y.-Y.; Zhang, L.; Chen, Z.; Zheng, B.-Y.; Ke, M.; Li, X.; Huang, J.-D. Nanostructured phthalocyanine assemblies with efficient synergistic effect of type I photoreaction and photothermal action to overcome tumor hypoxia in photodynamic therapy. J. Am. Chem. Soc. 2021, 143, 13980-13989. [CrossRef]

46. Liu, J.; Wang, F.; Qin, Y.; Feng, X. Advances in the genetically engineered killerred for photodynamic therapy applications. Int. J. Mol. Sci. 2021, 22, 10130. [CrossRef]

47. Zhao, X.; Dai, Y.; Ma, F.; Misal, S.; Hasrat, K.; Zhu, H.; Qi, Z. Molecular engineering to accelerate cancer cell discrimination and boost AIE-active type I photosensitizer for photodynamic therapy under hypoxia. Chem. Eng. J. 2021, 410, 128133. [CrossRef]

48. Ke, Z.; Xie, A.; Chen, J.; Zou, Z.; Shen, L.; Dai, Y.; Zou, D. Naturally available hypericin undergoes electron transfer for type I photodynamic and photothermal synergistic therapy. Biomater. Sci. 2020, 8, 2481-2487. [CrossRef]

49. Du, J.; Shi, T.; Long, S.; Chen, P.; Sun, W.; Fan, J.; Peng, X. Enhanced photodynamic therapy for overcoming tumor hypoxia: From microenvironment regulation to photosensitizer innovation. Co-Ord. Chem. Rev. 2021, 427, 213604. [CrossRef]

50. Luo, T.; Ni, K.; Culbert, A.; Lan, G.; Li, Z.; Jiang, X.; Kaufmann, M.; Lin, W. Nanoscale metal-organic frameworks stabilize bacteriochlorins for type I and type II photodynamic therapy. J. Am. Chem. Soc. 2020, 142, 7334-7339. [CrossRef] [PubMed]

51. Shi, Z.; Meng, X.; Zhang, K.; Tang, S.; Zhang, C.; Yang, Z.; Dong, H.; Zhang, X. Engineering structural metal-organic framework for hypoxia-tolerant type I photodynamic therapy against hypoxic cancer. ACS Mater. Lett. 2021, 3, 781-789. [CrossRef]

52. Zhang, X.; Huang, X.; Xie, A.; Zhang, X.; Deng, J.; Zou, D.; Zou, J. Boosting type I process of Ru(II) compounds by changing tetrazole ligand for enhanced photodynamic therapy against lung cancer. J. Inorg. Biochem. 2020, 212, 111236. [CrossRef] [PubMed]

53. Liu, X.; Li, G.; Xie, M.; Guo, S.; Zhao, W.; Li, F.; Liu, S.; Zhao, Q. Rational design of type I photosensitizers based on Ru(ii) complexes for effective photodynamic therapy under hypoxia. Dalton Trans. 2020, 49, 11192-11200. [CrossRef] [PubMed]

54. Yan, Y.W.; Zhang, K.X.; Wang, H.L.; Liu, W.; Zhang, Z.Z.; Liu, J.J.; Shi, J.J. A fullerene based hybrid nanoparticle facilitates enhanced photodynamic therapy via changing light source and oxygen consumption. Colloid Surf. B Biointerfaces 2020, 186, 110700. [CrossRef]

55. Ding, H.; Yu, H.; Dong, Y.; Tian, R.; Huang, G.; Boothman, D.A.; Sumer, B.D.; Gao, J. Photoactivation switch from type II to type I reactions by electron-rich micelles for improved photodynamic therapy of cancer cells under hypoxia. J. Control. Release 2011, 156, 276-280. [CrossRef] [PubMed]

56. Chen, D.; Yu, Q.; Huang, X.; Dai, H.; Luo, T.; Shao, J.; Chen, P.; Chen, J.; Huang, W.; Dong, X. A highly-efficient type I photosensitizer with robust vascular-disruption activity for hypoxic-and-metastatic tumor specific photodynamic therapy. Small 2020, 16, 2001059. [CrossRef]

57. Li, X.; Lee, D.; Huang, J.D.; Yoon, J. Phthalocyanine-assembled nanodots as photosensitizers for highly efficient type I photoreactions in photodynamic therapy. Angew. Chem. Int. Ed. 2018, 57, 9885-9890. [CrossRef]

58. Zhang, E.; Zuo, Z.; Yu, W.; Zhao, H.; Xia, S.; Huang, Y.; Lv, F.; Liu, L.; Li, Y.; Wang, S. Photoactive conjugated poly-mer/graphdiyne nanocatalyst for CO2 reduction to CO in living cells for hypoxia tumor treatment. Mat. Chem. Front. 2021, 5, 5841-5845. [CrossRef]

59. Vaupel, P.; Multhoff, G. Revisiting the Warburg effect: Historical dogma versus current understanding. J. Physiol. 2020, 599, 1745-1757. [CrossRef]

60. Moreno-Sánchez, R.; Rodriguez-Enriquez, S.; Marín-Hernández, Á.; Saavedra, E. Energy metabolism in tumor cells. FEBS J. 2007, 274, 1393-1418. [CrossRef]

61. Moreno-Sánchez, R.; Marín-Hernández, Á.; Saavedra, E.; Pardo, J.P.; Ralph, S.; Rodriguez-Enriquez, S. Who controls the ATP supply in cancer cells? Biochemistry lessons to understand cancer energy metabolism. Int. J. Biochem. Cell Biol. 2014, 50, 10-23. [CrossRef]

62. Dong, P.; Hu, J.; Yu, S.; Zhou, Y.; Shi, T.; Zhao, Y.; Wang, X.; Liu, X. A mitochondrial oxidative stress amplifier to overcome hypoxia resistance for enhanced photodynamic therapy. Small Methods 2021, 5, 2100581. [CrossRef]

63. Chen, D.; Suo, M.; Guo, J.; Tang, W.; Jiang, W.; Liu, Y.; Duo, Y. Development of MOF “armor-plated" phycocyanin and syn-ergistic inhibition of cellular respiration for hypoxic photodynamic therapy in patient-derived xenograft models. Adv. Healthc. Mater. 2020, 10, 2001577. [CrossRef] [PubMed]

64. Fan, Y.T.; Zhou, T.J.; Cui, P.F.; He, Y.J.; Chang, X.; Xing, L.; Jiang, H.L. Modulation of intracellular oxygen pressure by du-al-drug nanoparticles to enhance photodynamic therapy. Adv. Funct. Mater. 2019, 29, 1806708. [CrossRef]

65. Zhao, L.-P.; Zheng, R.-R.; Chen, H.-Q.; Liu, L.-S.; Zhao, X.-Y.; Liu, H.; Qiu, X.-Z.; Yu, X.-Y.; Cheng, H.; Li, S.-Y. Self-delivery nanomedicine for $\mathrm{O}_{2}$-economized photodynamic tumor therapy. Nano Lett. 2020, 20, 2062-2071. [CrossRef]

66. Xia, D.; Xu, P.; Luo, X.; Zhu, J.; Gu, H.; Huo, D.; Hu, Y. Overcoming hypoxia by multistage nanoparticle delivery system to inhibit mitochondrial respiration for photodynamic therapy. Adv. Funct. Mater. 2019, 29, 1807294. [CrossRef] 
67. Wang, D.; Xue, B.; Ohulchanskyy, T.; Liu, Y.; Yakovliev, A.; Ziniuk, R.; Xu, M.; Song, J.; Qu, J.; Yuan, Z. Inhibiting tumor oxygen metabolism and simultaneously generating oxygen by intelligent upconversion nanotherapeutics for enhanced photodynamic therapy. Biomaterials 2020, 251, 120088. [CrossRef]

68. Yuan, P.; Deng, F.; Liu, Y.; Zheng, R.; Rao, X.; Qiu, X.; Zhang, D.; Yu, X.; Cheng, H.; Li, S. Mitochondria targeted $\mathrm{O}_{2}$ economizer to alleviate tumor hypoxia for enhanced photodynamic therapy. Adv. Health Mater. 2021, 10, 2100198. [CrossRef]

69. Li, M.; Shao, Y.; Kim, J.H.; Pu, Z.; Zhao, X.; Huang, H.; Xiong, T.; Kang, Y.; Li, G.; Shao, K.; et al. Unimolecular photodynamic $\mathrm{O}_{2}$-economizer to overcome hypoxia resistance in phototherapeutics. J. Am. Chem. Soc. 2020, 142, 5380-5388. [CrossRef]

70. Yang, Z.J.; Chen, Q.; Chen, J.W.; Dong, Z.L.; Zhang, R.; Liu, J.J.; Liu, Z. Tumor-pH-responsive dissociable albumin-tamoxifen nanocomplexes enabling efficient tumor penetration and hypoxia relief for enhanced cancer photodynamic therapy. Small 2018, 14, 1803262. [CrossRef]

71. Yang, Z.; Wang, J.; Liu, S.; Li, X.; Miao, L.; Yang, B.; Zhang, C.; He, J.; Ai, S.; Guan, W. Defeating relapsed and refractory malignancies through a nano-enabled mitochondria-mediated respiratory inhibition and damage pathway. Biomaterials 2020, 229, 119580. [CrossRef] [PubMed]

72. Wang, X.; Ding, X.; Yu, B.; Zhang, X.; Shen, Y.; Cong, H. Tumor microenvironment-responsive polymer with chlorin e6 to interface hollow mesoporous silica nanoparticles-loaded oxygen supply factor for boosted photodynamic therapy. Nanotechnology 2020, 31, 305709. [CrossRef]

73. Jiang, W.; Zhang, C.; Ahmed, A.; Zhao, Y.L.; Deng, Y.; Ding, Y.; Cai, J.F.; Hu, Y. $\mathrm{H}_{2} \mathrm{O}_{2}$-sensitive upconversion nanocluster bomb for tri-mode imaging-guided photodynamic therapy in deep tumor tissue. Adv. Healthc. Mater. 2019, 8, 1900972. [CrossRef] [PubMed]

74. Yao, H.; Zhang, S.; Guo, X.; Li, Y.; Ren, J.; Zhou, H.; Du, B.; Zhou, J. A traceable nanoplatform for enhanced chemo-photodynamic therapy by reducing oxygen consumption. Nanomed. Nanotechnol. Biol. Med. 2019, 20, 101978. [CrossRef] [PubMed]

75. Zuo, H.Q.; Tao, J.X.; Shi, H.; He, J.; Zhou, Z.Y.; Zhang, C. Platelet-mimicking nanoparticles co-loaded with W18O49 and metformin alleviate tumor hypoxia for enhanced photodynamic therapy and photothermal therapy. Acta Biomater. 2018, 80, 296-307. [CrossRef] [PubMed]

76. Meng, X.; Song, J.; Lei, Y.; Zhang, X.; Chen, Z.; Lu, Z.; Zhang, L.; Wang, Z. A metformin-based nanoreactor alleviates hypoxia and reduces ATP for cancer synergistic therapy. Biomater. Sci. 2021, 9, 7456-7470. [CrossRef] [PubMed]

77. Zhao, M.; Yang, X.; Fu, H.; Chen, C.; Zhang, Y.; Wu, Z.; Duan, Y.; Sun, Y. Immune/hypoxic tumor microenvironment regu-lationenhanced photodynamic treatment realized by $\mathrm{pH}$-responsive phase transition-targeting nanobubbles. ACS Appl. Mater. Interfaces 2021, 13, 32763-32779. [CrossRef]

78. Yu, W.Y.; Liu, T.; Zhang, M.K.; Wang, Z.X.; Ye, J.J.; Li, C.X.; Liu, W.L.; Li, R.Q.; Feng, J.; Zhang, X.Z. O 2 economizer for in-hibiting cell respiration to combat the hypoxia obstacle in tumor treatments. ACS Nano 2019, 13, 1784-1794.

79. Xiang, Q.; Qiao, B.; Luo, Y.; Cao, J.; Fan, K.; Hu, X.; Hao, L.; Cao, Y.; Zhang, Q.; Wang, Z. Increased photodynamic therapy sensitization in tumors using a nitric oxide-based nanoplatform with ATP-production blocking capability. Theranostics 2021, 11, 1953-1969. [CrossRef]

80. Lan, Y.; Zhu, X.; Tang, M.; Wu, Y.; Zhang, J.; Liu, J.; Zhang, Y. Construction of a near-infrared responsive upconversion na-noplatform against hypoxic tumors via NO-enhanced photodynamic therapy. Nanoscale 2020, 12, 7875-7887. [CrossRef]

81. Li, W.; Yong, J.; Xu, Y.; Wang, Y.; Zhang, Y.; Ren, H.; Li, X. Glutathione depletion and dual-model oxygen balance disruption for photodynamic therapy enhancement. Colloids Surf. B Biointerfaces 2019, 183, 110453. [CrossRef]

82. Xiao, Z.; Halls, S.; Dickey, D.; Tulip, J.; Moore, R. Fractionated versus standard continuous light delivery in interstitial photodynamic therapy of dunning prostate carcinomas. Clin. Cancer Res. 2007, 13, 7496-7505. [CrossRef]

83. Turan, I.S.; Yildiz, D.; Turksoy, A.; Gunaydin, G.; Akkaya, E.U. A bifunctional photosensitizer for enhanced fractional photodynamic therapy: Singlet oxygen generation in the presence and absence of light. Angew. Chem. Int. Ed. 2016, 55, 2875-2878 [CrossRef] [PubMed]

84. De Souza, A.L.R.; Marra, K.; Gunn, J.; Samkoe, K.S.; Kanick, S.C.; Davis, S.C.; Chapman, M.S.; Maytin, E.V.; Hasan, T.; Pogue, B.W. Comparing desferrioxamine and light fractionation enhancement of ALA-PpIX photodynamic therapy in skin cancer. Br. J. Cancer 2016, 115, 805-813. [CrossRef]

85. Cosme, J.R.A.; Gagui, D.C.; Green, N.H.; Bryant, H.E.; Claeyssens, F. In vitro low-fluence photodynamic therapy parameter screening using 3D tumor spheroids shows that fractionated light treatments enhance phototoxicity. ACS Biomater. Sci. Eng. 2021, 7, 5078-5089. [CrossRef]

86. Zhang, P.; Wu, G.; Zhao, C.; Zhou, L.; Wang, X.; Wei, S. Magnetic stomatocyte-like nanomotor as photosensitizer carrier for photodynamic therapy based cancer treatment. Colloid Surf. B-Biointerfaces 2020, 194, 111204. [CrossRef] [PubMed]

87. Gao, C.; Lin, Z.; Wang, D.; Wu, Z.; Xie, H.; He, Q. Red blood cell-mimicking micromotor for active photodynamic cancer therapy. ACS Appl. Mater. Interfaces 2019, 11, 23392-23400. [CrossRef] [PubMed]

88. Gao, C.; Lin, Z.; Zhou, C.; Wang, D.; He, Q. Acoustophoretic motion of erythrocyte-mimicking hemoglobin micromotors. Chin. J. Chem. 2020, 38, 1589-1594. [CrossRef]

89. Li, Y.-H.; Zhou, S.; Jian, X.; Zhang, X.; Song, Y.-Y. Asymmetrically coating Pt nanoparticles on magnetic silica nanospheres for target cell capture and therapy. Microchim. Acta 2021, 188, 1-11. [CrossRef] [PubMed]

90. Li, H.; Sun, Z.; Jiang, S.; Lai, X.; Böckler, A.; Huang, H.; Peng, F.; Liu, L.; Chen, Y. Tadpole-like unimolecular nwith sub-100 nm size swims in a tumor microenvironment model. Nano Lett. 2019, 19, 8749-8757. [CrossRef] 
91. Peng, F.; Men, Y.; Tu, Y.; Chen, Y.; Wilson, D.A. Nanomotor-based strategy for enhanced penetration across vasculature model. Adv. Funct. Mater. 2018, 28, 1706117. [CrossRef]

92. Zhou, T.-J.; Xing, L.; Fan, Y.-T.; Cui, P.-F.; Jiang, H.-L. Light triggered oxygen-affording engines for repeated hypoxia-resistant photodynamic therapy. J. Control. Release 2019, 307, 44-54. [CrossRef] [PubMed]

93. Huo, M.; Wang, L.; Zhang, L.; Wei, C.; Chen, Y.; Shi, J. Photosynthetic tumor oxygenation by photosensitizer-containing cyanobacteria for enhanced photodynamic therapy. Angew. Chem. Int. Ed. 2020, 59, 1906-1913. [CrossRef] [PubMed]

94. Sun, T.; Zhang, Y.; Zhang, C.; Wang, H.; Pan, H.; Liu, J.; Li, Z.; Chen, L.; Chang, J.; Zhang, W. Cyanobacteria-based bio-oxygen pump promoting hypoxia-resistant photodynamic therapy. Front. Bioeng. Biotechnol. 2020, 8, 237. [CrossRef] [PubMed]

95. Liu, L.; He, H.; Luo, Z.; Zhou, H.; Liang, R.; Pan, H.; Ma, Y.; Cai, L. In situ photocatalyzed oxygen generation with photosynthetic bacteria to enable robust immunogenic photodynamic therapy in triple-negative breast cancer. Adv. Funct. Mater. 2020, 30, 1910176. [CrossRef]

96. He, C.; Dong, C.; Hu, H.; Yu, L.; Chen, Y.; Hao, Y. Photosynthetic oxygen-self-generated 3D-printing microbial scaffold en-hances osteosarcoma elimination and prompts bone regeneration. Nano Today 2021, 41, 101297. [CrossRef]

97. Qi, F.; Ji, P.; Chen, Z.; Wang, L.; Yao, H.; Huo, M.; Shi, J. Photosynthetic cyanobacteria-hybridized black phosphorus nanosheets for enhanced tumor photodynamic therapy. Small 2021, 17, 2102113. [CrossRef]

98. Zhang, X.; Zhang, Y.; Zhang, C.; Yang, C.; Tian, R.; Sun, T.; Zhang, W.; Chang, J.; Wang, H. An injectable hydrogel co-loading with cyanobacteria and upconversion nanoparticles for enhanced photodynamic tumor therapy. Colloids Surf. B Biointerfaces 2021, 201, 111640. [CrossRef]

99. Zhong, D.; Li, W.; Qi, Y.; He, J.; Zhou, M. Photosynthetic biohybrid nanoswimmers system to alleviate tumor hypoxia for FL/PA/MR imaging-guided enhanced radio-photodynamic synergetic therapy. Adv. Funct. Mater. 2020, 30, 1910395. [CrossRef]

100. Zhang, Y.; Liu, H.; Dai, X.; Li, H.; Zhou, X.; Chen, S.; Zhang, J.; Liang, X.-J.; Li, Z. Cyanobacteria-based near-infrared light-excited self-supplying oxygen system for enhanced photodynamic therapy of hypoxic tumors. Nano Res. 2021, 14, 667-673. [CrossRef]

101. Wang, H.; Guo, Y.; Wang, C.; Jiang, X.; Liu, H.; Yuan, A.; Yan, J.; Hu, Y.; Wu, J. Light-controlled oxygen production and collection for sustainable photodynamic therapy in tumor hypoxia. Biomaterials 2021, 269, 120621. [CrossRef] [PubMed]

102. Li, W.; Zhong, D.; Hua, S.; Du, Z.; Zhou, M. Biomineralized biohybrid algae for tumor hypoxia modulation and cascade radio-photodynamic therapy. ACS Appl. Mater. Interfaces 2020, 12, 44541-44553. [CrossRef] [PubMed]

103. Zheng, D.; Li, B.; Xu, L.; Zhang, Q.L.; Fan, J.X.; Li, C.X.; Zhang, X.Z. Normalizing tumor microenvironment based on photosynthetic abiotic/biotic nanoparticles. ACS Nano 2018, 12, 6218-6227. [CrossRef]

104. Cheng, Y.; Zheng, R.; Wu, X.; Xu, K.; Song, P.; Wang, Y.; Yan, J.; Chen, R.; Li, X.; Zhang, H. Thylakoid membranes with unique photosystems used to simultaneously produce self-supplying oxygen and singlet oxygen for hypoxic tumor therapy. Adv. Health Mater. 2021, 10, e2001666. [CrossRef] [PubMed]

105. Berry, J.; Bjorkman, O. Phtosynthetic response and adaptation to temperature in higher-plants. Annu. Rev. Plant Physiol. Plant Mol. Biol. 1980, 31, 491-543. [CrossRef]

106. Santarius, K.A. Sites of heat sensitivity in chloroplasts and differential inactivation of cyclic and noncyclic photophosphory-lation by heating. J. Therm. Biol. 1976, 1, 101-107. [CrossRef]

107. Spahn, D.R. Blood substitutes Artificial oxygen carriers: Perfluorocarbon emulsions. Crit. Care 1999, 3, R93-R97. [CrossRef]

108. Cheng, X.; Li, H.; Ge, X.; Chen, L.; Liu, Y.; Mao, W.; Zhao, B.; Yuan, W.-E. Tumor-microenvironment- responsive size-shrinkable drug-delivery nanosystems for deepened penetration into tumors. Front. Mol. Biosci. 2020, 7, 576420. [CrossRef]

109. Chen, W.H.; Sun, Z.; Jiang, C.H.; Sun, W.B.; Yu, B.; Wang, W.; Lu, L.H. An all-in-one organic semiconductor for targeted photoxidation catalysis in hypoxic tumor. Angew. Chem. Int. Ed. 2021, 60, 16641-16648. [CrossRef] [PubMed]

110. Zheng, D.-W.; Li, B.; Li, C.-X.; Fan, J.-X.; Lei, Q.; Li, C.; Xu, Z.; Zhang, X.-Z. Carbon-dot-decorated carbon nitride nanoparticles for enhanced photodynamic therapy against hypoxic tumor via water splitting. ACS Nano 2016, 10, 8715-8722. [CrossRef]

111. Cheng, H.L.; Guo, H.L.; Xie, A.J.; Shen, Y.H.; Zhu, M.Z. 4-in-1 Fe3O4/g-C3N4@PPy-DOX nanocomposites: Magnetic targeting guided trimode combinatorial chemotherapy/PDT/PTT for cancer. J. Inorg. Biochem. 2021, 215, 111329. [CrossRef] [PubMed]

112. Wang, S.; Zhang, C.; Liu, X.; Chen, Z.; Peng, S.; Zhong, Z.; Zhang, X. A tungsten nitride-based $\mathrm{O}_{2}$ self-sufficient nanoplatform for enhanced photodynamic therapy against hypoxic tumors. Adv. Ther. 2019, 2, 1900012. [CrossRef]

113. Yang, D.; Yang, G.; Sun, Q.; Gai, S.; He, F.; Dai, Y.; Zhong, C.; Yang, P. Carbon-dot-decorated TiO 2 nanotubes toward photodynamic therapy based on water-splitting mechanism. Adv. Healthc. Mater. 2018, 7, 1800042. [CrossRef] [PubMed]

114. Jiang, W.; Zhang, Z.; Wang, Q.; Dou, J.; Zhao, Y.; Ma, Y.; Liu, H.; Xu, H.; Wang, Y. Tumor reoxygenation and blood perfusion enhanced photodynamic therapy using ultrathin graphdiyne oxide nanosheets. Nano Lett. 2019, 19, 4060-4067. [CrossRef]

115. Li, M.; Lin, H.; Qu, F. FeS2@C-ICG-PEG nanostructure with intracellular $\mathrm{O}_{2}$ generation for enhanced photo-dynamic/thermal therapy and imaging. Chem. Eng. J. 2020, 384, 123374. [CrossRef]

116. Yang, Z.; Liu, X.; Wang, X.; Wang, P.; Ruan, S.; Xie, A.; Shen, Y.; Zhu, M. 4-in-1 phototheranostics: PDA@CoPA-LA nano-composite for photothermal imaging/photothermal/in-situ $\mathrm{O}_{2}$ generation/photodynamic combination therapy. Chem. Eng. J. 2020, 387, 124113. [CrossRef]

117. Huang, Y.; Tian, Y.; Shu, J.; Wang, F.; Wei, X. Oxygen self-enriched single-component "black carbon nitride" for near-infrared phototheranostics. Nanoscale 2020, 12, 21812-21820. [CrossRef]

118. Li, R.-Q.; Zhang, C.; Xie, B.-R.; Yu, W.-Y.; Qiu, W.-X.; Cheng, H.; Zhang, X.-Z. A two-photon excited O 2 -evolving nanocomposite for efficient photodynamic therapy against hypoxic tumor. Biomaterials 2019, 194, 84-93. [CrossRef] 
119. Yang, L.; Wei, Y.; Xing, D.; Chen, Q. Increasing the efficiency of photodynamic therapy by improved light delivery and oxygen supply using an anticoagulant in a solid tumor model. Lasers Surg. Med. 2010, 42, 671-679. [CrossRef]

120. Hu, D.; Sheng, Z.; Gao, G.; Siu, F.; Liu, C.; Wan, Q.; Gong, P.; Zheng, H.; Ma, Y.; Cai, L. Activatable albumin-photosensitizer nanoassemblies for triple-modal imaging and thermal-modulated photodynamic therapy of cancer. Biomaterials 2016, 93, 10-19. [CrossRef]

121. Wang, M.; Zhao, J.; Zhang, L.; Wei, F.; Lian, Y.; Wu, Y.; Gong, Z.; Zhang, S.; Zhou, J.; Cao, K.; et al. Role of tumor microenvironment in tumorigenesis. J. Cancer 2017, 8, 761-773. [CrossRef]

122. Yang, N.; Xiao, W.; Song, X.; Wang, W.; Dong, X. Recent advances in tumor microenvironment hydrogen peroxide-responsive materials for cancer photodynamic therapy. Nano Micro Lett. 2020, 12, 1-27. [CrossRef]

123. Wang, C.; Li, Y.; Yang, W.; Zhou, L.; Wei, S. Nanozyme with robust catalase activity by multiple mechanisms and its application for hypoxic tumor treatment. Adv. Healthc. Mater. 2021, 10, 2100601. [CrossRef]

124. Liu, J.; Wang, L.; Shen, X.; Gao, X.; Chen, Y.; Liu, H.; Liu, Y.; Yin, D.; Liu, Y.; Xu, W.; et al. Graphdiyne-templated palladiumnanoparticle assembly as a robust oxygen generator to attenuate tumor hypoxia. Nano Today 2020, 34, 100907. [CrossRef]

125. Xu, T.; Zhu, X.; Yang, L.; Bu, Y.; Zhang, Y.; Zhang, J.; Wang, L.; Yu, Z.; Zhou, H. Defective transition metal hydroxide-based nanoagents with hypoxia relief for photothermal-enhanced photodynamic therapy. J. Mater. Chem. B 2020, 9, 1018-1029. [CrossRef]

126. $\mathrm{Mu}$, J.; Zhang, L.; Zhao, M.; Wang, Y. Co3O4 nanoparticles as an efficient catalase mimic: Properties, mechanism and its electrocatalytic sensing application for hydrogen peroxide. J. Mol. Catal. A Chem. 2013, 378, 30-37. [CrossRef]

127. Wu, J.; Niu, S.; Bremner, D.H.; Nie, W.; Fu, Z.; Li, D.; Zhu, L.M. A tumor microenvironment-responsive biodegradable mesoporous nanosystem for anti-inflammation and cancer theranostics. Adv. Healthc. Mater. 2020, 9, 1901307. [CrossRef]

128. Yuan, X.Y.; Cen, J.Q.; Chen, X.; Jia, Z.; Zhu, X.F.; Huang, Y.Q.; Yuan, G.L.; Liu, J. Iridium oxide nanoparticles mediated enhanced photodynamic therapy combined with photothermal therapy in the treatment of breast cancer. J. Colloid Interface Sci. 2022, 605, 851-862. [CrossRef] [PubMed]

129. Yao, C.; Wang, W.; Wang, P.; Zhao, M.; Li, X.; Zhang, F. Near-infrared upconversion mesoporous cerium oxide hollow biophotocatalyst for concurrent $\mathrm{pH}-/ \mathrm{H}_{2} \mathrm{O}_{2}$-responsive $\mathrm{O}_{2}$-evolving synergetic cancer therapy. Adv. Mater. 2018, 30, 1704833. [CrossRef] [PubMed]

130. Hu, Z.; Ding, Y. Cerium oxide nanoparticles-mediated cascade catalytic chemo-photo tumor combination therapy. Nano Res. 2021, 15, 1-13. [CrossRef]

131. Dong, P.; Wang, W.; Pan, M.; Yu, W.; Liu, Y.; Shi, T.; Hu, J.; Zhou, Y.; Yu, S.; Wang, F.; et al. cascaded amplifier nanoreactor for efficient photodynamic therapy. ACS Appl. Mater. Interfaces 2021, 13, 16075-16083. [CrossRef]

132. Yang, X.; Liu, R.; Zhong, Z.; Huang, H.; Shao, J.; Xie, X.; Zhang, Y.; Wang, W.; Dong, X. Platinum nanoenzyme functionalized black phosphorus nanosheets for photothermal and enhanced-photodynamic therapy. Chem. Eng. J. 2021, 409, 127381. [CrossRef]

133. Liu, C.-P.; Wu, T.-H.; Liu, C.-Y.; Chen, K.-C.; Chen, Y.-X.; Chen, G.-S.; Lin, S.-Y. Self-supplying O2 through the catalase-like activity of gold nanoclusters for photodynamic therapy against hypoxic cancer cells. Small 2017, 13, 1700278. [CrossRef] [PubMed]

134. Lan, G.; Ni, K.; Xu, Z.; Veroneau, S.; Song, Y.; Lin, W. Nanoscale metal-organic framework overcomes hypoxia for photodynamic therapy primed cancer immunotherapy. J. Am. Chem. Soc. 2018, 140, 5670-5673. [CrossRef] [PubMed]

135. Hou, H.; Huang, X.; Wei, G.; Xu, F.; Wang, Y.; Zhou, S. Fenton reaction-assisted photodynamic therapy for cancer with multifunctional magnetic nanoparticles. ACS Appl. Mater. Interfaces 2019, 11, 29579-29592. [CrossRef]

136. Shi, L.; Hu, F.; Duan, Y.; Wu, W.; Dong, J.; Meng, X.; Zhu, X.; Liu, B. Hybrid nanospheres to overcome hypoxia and intrinsic oxidative resistance for enhanced photodynamic therapy. ACS Nano 2020, 14, 2183-2190. [CrossRef] [PubMed]

137. Zhang, T.; Jiang, Z.; Chen, L.; Pan, C.; Sun, S.; Liu, C.; Li, Z.; Ren, W.; Wu, A.; Huang, P. PCN-Fe(III)-PTX nanoparticles for MRI guided high efficiency chemo-photodynamic therapy in pancreatic cancer through alleviating tumor hypoxia. Nano Res. 2020, 13, 273-281. [CrossRef]

138. Rajalakshmi, R.; Mahesh, K.; Kumar, C.K. A critical review on nano emulsions. Int. J. Innov. Drug Dis. 2011, 1, 1-8.

139. Rich, L.; Damasco, J.; Bulmahn, J.; Kutscher, H.; Prasad, P.; Seshadri, M. Photoacoustic and magnetic resonance imaging of hybrid manganese dioxide-coated ultra-small $\mathrm{NaGdF}_{4}$ nanoparticles for spatiotemporal modulation of hypoxia in head and neck cancer. Cancers 2020, 12, 3294. [CrossRef]

140. Li, S.Y.; Zhao, L.P.; Zheng, R.R.; Fan, G.L.; Liu, L.S.; Zhou, X.; Chen, X.T.; Qiu, X.Z.; Yu, X.Y.; Cheng, H. Tumor microenvi-ronment adaptable nanoplatform for $\mathrm{O}_{2}$ self-sufficient chemo/photodynamic combination therapy. Part. Part. Syst. Charact. 2020, 37, 1900496. [CrossRef]

141. Nwahara, N.; Abrahams, G.; Prinsloo, E.; Nyokong, T. Folic acid-modified phthalocyanine-nanozyme loaded liposomes for targeted photodynamic therapy. Photodiagn. Photodyn. Ther. 2021, 36, 102527. [CrossRef]

142. Wu, F.; Zhang, Q.; Sun, B.; Chu, X.; Zhang, M.; She, Z.; Li, Z.; Zhou, N.; Wang, J.; Li, A. MoO3-x nanosheets-based platform for single NIR laser induced efficient PDT/PTT of cancer. J. Control. Release 2021, 338, 46-55. [CrossRef]

143. Zhu, D.; Wang, B.; Zhu, X.-H.; Zhu, H.-L.; Ren, S.-Z. A $\mathrm{MnO}_{2}$-coated multivariate porphyrinic metal-organic framework for oxygen self-sufficient chemo-photodynamic synergistic therapy. Nanomed. Nanotechnol. Biol. Med. 2021, 37, 102440. [CrossRef]

144. Zhang, L.; Yang, Z.; He, W.; Ren, J.; Wong, C.-Y. One-pot synthesis of a self-reinforcing cascade bioreactor for combined photodynamic/chemodynamic/starvation therapy. J. Colloid Interface Sci. 2021, 599, 543-555. [CrossRef] [PubMed] 
145. Chen, M.; Song, J.; Zhu, J.; Hong, G.; An, J.; Feng, E.; Peng, X.; Song, F. A dual-nanozyme-catalyzed cascade reactor for en-hanced photodynamic oncotherapy against tumor hypoxia. Adv. Healthc. Mater. 2021, 10, 2101049. [CrossRef] [PubMed]

146. Li, J.; Zhou, C.; Zhang, J.; Xu, F.; Zheng, Y.; Wang, S.; Zou, D. Photo-induced tumor therapy using $\mathrm{MnO}_{2} / \mathrm{IrO}_{2}-\mathrm{PVP}$ nano-enzyme with TME-responsive behaviors. Colloid Surf. B Biointerfaces 2021, 205, 111852. [CrossRef] [PubMed]

147. Wu, Y.; Chen, Z.; Yao, Z.; Zhao, K.; Shao, F.; Su, J.; Liu, S. Black Phosphorus quantum dots encapsulated biodegradable hollow mesoporous $\mathrm{MnO}_{2}$ : Dual-modality cancer imaging and synergistic chemo-phototherapy. Adv. Funct. Mater. 2021, 31, 2104643. [CrossRef]

148. Liu, P.; Zhou, Y.; Shi, X.; Yuan, Y.; Peng, Y.; Hua, S.; Luo, Q.; Ding, J.; Li, Y.; Zhou, W. A cyclic nano-reactor achieving en-hanced photodynamic tumor therapy by reversing multiple resistances. J. Nanobiotechnol. 2021, 19, 149. [CrossRef] [PubMed]

149. Liu, P.; Xie, X.; Liu, M.; Hu, S.; Ding, J.; Zhou, W. A smart $\mathrm{MnO}_{2}$-doped graphene oxide nanosheet for enhanced chemophotodynamic combinatorial therapy via simultaneous oxygenation and glutathione depletion. Acta Pharm. Sin. B 2021, 11, 823-834. [CrossRef]

150. Huang, Y.; Shen, K.; Si, Y.; Shan, C.; Guo, H.; Chen, M.; Wu, L. Dendritic organosilica nanospheres with large mesopores as multi-guests vehicle for photoacoustic/ultrasound imaging-guided photodynamic therapy. J. Colloid Interface Sci. 2021, 583, 166-177. [CrossRef]

151. Zhu, T.; Shi, L.; Ma, C.; Xu, L.; Yang, J.; Zhou, G.; Zhu, X.; Shen, L. Fluorinated chitosan-mediated intracellular catalase delivery for enhanced photodynamic therapy of oral cancer. Biomater. Sci. 2021, 9, 658-662. [CrossRef] [PubMed]

152. Li, Z.; Yin, Y.; Jin, W.; Zhang, B.; Yan, H.; Mei, H.; Wang, H.; Guo, T.; Shi, W.; Hu, Y. Tissue factor-targeted “O${ }_{2}$-Evolving” nanoparticles for photodynamic therapy in Malignant Lymphoma. Front. Oncol. 2020, 10, 524712. [CrossRef]

153. Shen, L.; Huang, Y.; Chen, D.; Qiu, F.; Ma, C.; Jin, X.; Zhu, X.; Zhou, G.; Zhang, Z. PH-responsive aerobic nanoparticles for effective photodynamic therapy. Theranostics 2017, 7, 4537-4550. [CrossRef]

154. Zhou, R.; Ohulchanskyy, T.Y.; Xu, H.; Ziniuk, R.; Qu, J. Catalase nanocrystals loaded with methylene blue as oxygen self-supplied, imaging-guided platform for photodynamic therapy of hypoxic tumors. Small 2021, 17, 2103569. [CrossRef]

155. Shi, C.; Li, M.; Zhang, Z.; Yao, Q.; Shao, K.; Xu, F.; Xu, N.; Li, H.; Fan, J.; Sun, W.; et al. Cata-lase-based liposomal for reversing immunosuppressive tumor microenvironment and enhanced cancer chemo-photodynamic therapy. Biomaterials 2020, 233,119755 [CrossRef]

156. Deng, X.; Yang, W.; Shao, Z.; Zhao, Y. Genetically modified bacteria for targeted phototherapy of tumor. Biomaterials 2021, 272, 120809. [CrossRef]

157. Ding, S.; Liu, Z.; Huang, C.; Zeng, N.; Jiang, W.; Li, Q. Novel engineered bacterium/black phosphorus quantum dot hybrid system for hypoxic tumor targeting and efficient photodynamic therapy. ACS Appl. Mater. Interfaces 2021, 13, 10564-10573. [CrossRef]

158. Cheng, X.; He, L.; Xu, J.; Fang, Q.; Yang, L.; Xue, Y.; Wang, X.; Tang, R. Oxygen-producing catalase-based prodrug nanoparticles overcoming resistance in hypoxia-mediated chemo-photodynamic therapy. Acta Biomater. 2020, 112, 234-249. [CrossRef] [PubMed]

159. Hong, L.; Zhang, J.; Geng, J.; Qu, J.; Liu, L. Development of a hydrogen peroxide-responsive and oxygen-carrying nanoemul-sion for photodynamic therapy against hypoxic tumors using phase inversion composition method. J. Innov. Opt. Health Sci. 2021, 14, 2150003. [CrossRef]

160. Zhang, C.; Qin, W.-J.; Bai, X.-F.; Zhang, X.-Z. Nanomaterials to relieve tumor hypoxia for enhanced photodynamic therapy. Nano Today 2020, 35, 100960. [CrossRef]

161. Riggs, A.F. The Bohr effect. Annu. Rev. Physiol. 1988, 50, 181-204. [CrossRef]

162. Jia, Q.; Ge, J.; Liu, W.; Zheng, X.; Chen, S.; Wen, Y.; Zhang, H.; Wang, P. A Magnetofluorescent carbon dot assembly as an acidic $\mathrm{H} 2 \mathrm{O} 2$-driven oxygenerator to regulate tumor hypoxia for simultaneous bimodal imaging and enhanced photodynamic therapy. Adv. Mater. 2018, 30, e1706090. [CrossRef] [PubMed]

163. Buehler, P.W.; Zhou, Y.; Cabrales, P.; Jia, Y.; Sun, G.; Harris, D.R.; Tsai, A.G.; Intaglietta, M.; Palmer, A.F. Synthesis, biophysical properties and pharmacokinetics of ultrahigh molecular weight tense and relaxed state polymerized bovine hemoglobins. Biomaterials 2010, 31, 3723-3735. [CrossRef]

164. Chen, Z.; Liu, L.; Liang, R.; Luo, Z.; He, H.; Wu, Z.; Tian, H.; Zheng, M.; Ma, Y.; Cai, L. Bioinspired hybrid protein oxygen nanocarrier amplified photodynamic therapy for eliciting anti-tumor immunity and abscopal effect. ACS Nano 2018, 12, 8633-8645. [CrossRef]

165. Guo, X.; Qu, J.; Zhu, C.; Li, W.; Luo, L.; Yang, J.; Yin, X.; Li, Q.; Du, Y.; Chen, D.; et al. Synchronous delivery of oxygen and photosensitizer for alleviation of hypoxia tumor microenvironment and dramatically enhanced photodynamic therapy. Drug Deliv. 2018, 25, 585-599. [CrossRef]

166. Xu, T.; Ma, Y.; Yuan, Q.; Hu, H.; Hu, X.; Qian, Z.; Rolle, J.K.; Gu, Y.; Li, S. Enhanced ferroptosis by oxygen-boosted photo-therapy based on 2-in-1 nanoplatform of ferrous hemoglobin for tumor synergistic therapy. ACS Nano 2020, 14, 3414-3425. [CrossRef]

167. Shi, X.; Zhan, Q.; Yan, X.; Zhou, J.; Zhou, L.; Wei, S. Oxyhemoglobin nano-recruiter preparation and its application in bio-mimetic red blood cells to relieve tumor hypoxia and enhance photodynamic therapy activity. J. Mat. Chem. B 2020, 8, 534-545. [CrossRef] [PubMed] 
168. Shi, X.; Yang, W.; Ma, Q.; Lu, Y.; Xu, Y.; Bian, K.; Liu, F.; Shi, C.; Wang, H.; Shi, Y.; et al. Hemoglobin-mediated biomimetic synthesis of paramagnetic $\mathrm{O}_{2}$-evolving theranostic nanoprobes for MR imaging-guided enhanced photodynamic therapy of tumor. Theranostics 2020, 10, 11607-11621. [CrossRef] [PubMed]

169. Liu, W.-L.; Liu, T.; Zou, M.; Yu, W.; Li, C.; He, Z.; Zhang, M.; Liu, M.; Li, Z.; Feng, J.; et al. Aggressive man-made red blood cells for hypoxia-resistant photodynamic therapy. Adv. Mater. 2018, 30, e1802006. [CrossRef]

170. Wang, P.; Wang, X.; Luo, Q.; Li, Y.; Lin, X.; Fan, L.; Zhang, Y.; Liu, J.; Liu, X. Fabrication of red blood cell-based multimodal theranostic probes for second near-infrared window fluorescence imaging-guided tumor surgery and photodynamic therapy. Theranostics 2019, 9, 369-380. [CrossRef] [PubMed]

171. Hong, L.; Wang, J.-L.; Geng, J.-X.; Zhao, Y.-H.; Zhou, G.-X.; Zhang, J.; Liu, L.-W.; Qu, J.-L. Rational design of an oxygen-enriching nanoemulsion for enhanced near-infrared laser activatable photodynamic therapy against hypoxic tumors. Colloids Surf. B Biointerfaces 2021, 198, 111500. [CrossRef]

172. Cheng, Y.; Jiang, C.; Qiu, X.; Wang, K.; Huan, W.; Yuan, A.; Wu, J.; Hu, Y. Perfluorocarbon nanoparticles enhance reactive oxygen levels and tumour growth inhibition in photodynamic therapy. Nat. Commun. 2015, 6, 8785. [CrossRef]

173. Ren, H.; Liu, J.Q.; Su, F.H.; Ge, S.Z.; Yuan, A.; Dai, W.M.; Wu, J.H.; Hu, Y.Q. Relighting photosensitizers by synergistic inte-gration of albumin and perfluorocarbon for enhanced photodynamic therapy. ACS Appl. Mater. Interfaces 2017, 9, 3463-3473. [CrossRef]

174. Wang, H.-Y.; Hou, L.; Li, H.-L.; Wang, X.; Cao, Y.; Zhang, B.-Y.; Wang, J.-T.; Wei, S.-J.; Dang, H.-W.; Ran, H.-T. A nanosystem loaded with perfluorohexane and rose bengal coupled upconversion nanoparticles for multimodal imaging and synergetic chemo-photodynamic therapy of cancer. Biomater. Sci. 2020, 8, 2488-2506. [CrossRef]

175. Yan, K.; Mu, C.; Wang, D.; Jing, X.; Zhang, N.; Meng, L. Yolk-shell polyphosphazenes nanotheranostics for multimodal imaging guided effective phototherapy. Compos. Commun. 2021, 28, 100950. [CrossRef]

176. Kv, R.; Liu, T.-I.; Lu, I.-L.; Liu, C.-C.; Chen, H.-H.; Lu, T.-Y.; Chiang, W.-H.; Chiu, H.-C. Tumor microenvironment-responsive and oxygen self-sufficient oil droplet nanoparticles for enhanced photothermal/photodynamic combination therapy against hypoxic tumors. J. Control. Release 2020, 328, 87-99. [CrossRef]

177. Tao, D.; Feng, L.; Chao, Y.; Liang, C.; Song, X.; Wang, H.; Yang, K.; Liu, Z. Covalent organic polymers based on fluorinated porphyrin as oxygen nanoshuttles for tumor hypoxia relief and enhanced photodynamic therapy. Adv. Funct. Mater. 2018, 28, 1804901. [CrossRef]

178. Ren, H.; Liu, J.; Li, Y.; Wang, H.; Ge, S.; Yuan, A.; Hu, Y.; Wu, J. Oxygen self-enriched nanoparticles functionalized with erythrocyte membranes for long circulation and enhanced phototherapy. Acta Biomater. 2017, 59, 269-282. [CrossRef] [PubMed]

179. Liang, X.; Chen, M.; Bhattarai, P.; Hameed, S.; Dai, Z. Perfluorocarbon@Porphyrin nanoparticles for tumor hypoxia relief to enhance photodynamic therapy against liver metastasis of colon cancer. ACS Nano 2020, 14, 13569-13583. [CrossRef] [PubMed]

180. Gao, S.; Zheng, P.; Li, Z.; Feng, X.; Yan, W.; Chen, S.; Guo, W.; Liu, D.; Yang, X.; Wang, S.; et al. Biomimetic O ${ }_{2}$-evolving metal-organic framework nanoplatform for highly efficient photodynamic therapy against hypoxic tumor. Biomaterials 2018, 178, 83-94. [CrossRef] [PubMed]

181. Xie, Z.; Cai, X.; Sun, C.; Liang, S.; Shao, S.; Huang, S.; Cheng, Z.; Pang, M.; Xing, B.; Kheraif, A.A.A.; et al. O O-loaded pHresponsive multifunctional nanodrug carrier for overcoming hypoxia and highly efficient chemo-photodynamic cancer therapy. Chem. Mater. 2019, 31, 483-490. [CrossRef] 